\title{
Microalgae, Functional Genomics and Biotechnology
}

\author{
Jean-Paul Cadoret, Matthieu Garnier, Bruno Saint-Jean
}

\begin{abstract}
Ifremer, Laboratoire Physiologie et Biotechnologie des Algues, rue de l'île d'Yeu BP 2110544311 Nantes cedex 3, France

*: Corresponding author : Jean-Paul Cadoret, email address : jean.paul.cadoret@ifremer.fr
\end{abstract}

\begin{abstract}
:
Microalgae have been studied for decades, but a new wave of research has recently begun as part of the search for renewable and sustainable energy sources. For economic optimization, microalgal biomass is being considered as a whole (main products and co-products) in an overall 'biorefinery' concept. Applications of microalgae cover a broad spectrum, including the food and (livestock) feed industries, bioenergy, cosmetics, healthcare and environmental restoration or protection. In the field of biotechnology, the access to genomic data is playing a growing role. As the cost of sequencing strategies has fallen, studies of gene function at the transcript, protein and biosynthesis pathway levels have multiplied. Notably, sequencing and mass spectrometry technologies are used to delineate the pathways of lipid synthesis, which will be valuable for the future application of microalgae in the biotechnology and biofuel industries. Another field making an applied use of genomics is the 'cell factory' approach, which uses the cell to manufacture (express) natural or recombinant proteins for diverse purposes. In this chapter, we present a vision of the potential future of genomics in the biotechnology of microalgae from several points of view.
\end{abstract}

Keywords: Microalgae ; Genomics ; Post-genomics ; Biotechnology ; Molecular farming ; Cell factory ; Domestication ; Biofuel ; Lipid ; Natural compound ; Biodiversity 


\section{Introduction}

Microalgae in biotechnology are presently the focus of an unprecedented surge in interest and investment worldwide. Over recent decades, research predicted the explosion of attention this field would attact following the US Aquatic Species Program (Sheehan et al., 1998), as microalgae can provide a new source of vegetal material. They offer complementary products to land plants and higher manipulability, but as the consequence of their large phylogenetic spread (reviewed in chapter I of this volume), they have vast unknown metabolic potential because most species are, as yet, unexamined.

Driven by the giants of the energy industry, the race to develop mass microalgal production capacity started about five years ago, fuelled by hundreds of millions of US dollars targeting the production of renewable biofuels. The challenges we face today are to adapt and improve existing methods, develop new processes, and achieve a drastic reduction in costs. The objective is to use this green biomass in its entirety and not only for energy production. The potential is huge and the fields of study numerous, offering very high added value in the areas of new energy (oil, hydrogen and fermentation), healthcare (pigments, enzymes and secondary metabolites), food (human or animal), environmental management (depuration and assimilation mechanisms) and industry (recovery of silica, enzymes or pigments). Here, we have chosen to focus our presentation on the world of microalgae, their broad fields of application, the advances in genomics for biotechnologies and some of the bottlenecks that need to be overcome.

\subsection{Microalgae}

We use the term microalgae to cover a heterogeneous group of single-celled photosynthetic organisms, including photosynthetic eukaryotes and photosynthetic prokaryotes like Prochlorococcus and Synechococcus, which are of major global importance and considered as key players among phytoplanktonic organisms in oligotrophic oceanic areas. It would be vastly overambitious to attempt to cover the biotechnological potential of the entire aquatic photosynthetic world in one book chapter, so this review will address only the genomics and biotechnology of eukaryotic microalgae.

Depending on environmental conditions such as salinity, light, temperature, $\mathrm{pH}$ and nutrient concentrations, the size and appearance of microalgae can change profoundly, making their identification difficult without molecular tools. The estimated number of described species ranges between 40000 and 60000 , but estimations of the number of undescribed species range from hundreds of thousands to millions of species spread over the globe (Norton et al., 1996, Sastre and Posten, 2010). In comparison, only 250000 land plant species have been recorded. Half of the world's oxygen is produced via microalgal photosynthesis. Microalgae contribute up to $50 \%$ of all aquatic productivity and $25 \%$ of global productivity (Raven and Falkowski, 1999). They are the foundation of the aquatic food chain and have colonised nearly all biotopes, from the polar ice to deserts and hot springs. They have adapted to extreme environments, living in salt marshes, acidic environments or conditions with very low light. Through their presence on the surface of the oceans, which cover $70 \%$ of the earth, they play a major role in global climate regulation, as a machine that transforms $\mathrm{CO}_{2}$ into organic matter (Raven and Falkowski, 1999).

Ancestors of the present day cyanobacteria invented photosynthesis as far back as 3.6 billion years ago (Gould et al., 2008) and the primary endosymbiotic event at the origin of all photosynthetic eukaryotes can be traced to 1.8 billion years ago, (Finazzi et al., 2010). The number and the diversity of algal species offer a whole new field of research when considering their potential commercial applications and biotechnology. Although progress still needs to be made on culture techniques, algal production systems on scales from a few litres up to cubic metre volumes, in photobioreactors or open ponds, are now a reality at the 
industrial level. Microalgae have clear advantages over land plants. Their photosynthetic yields are slightly better than those of land plants (Wijffels et al., 2010), and the fact that they live in an aqueous medium gives them direct access to their nutrients and explains why they display higher growth productivity. As an example, the productivity of classic crops in Europe is around 1 to $2 \mathrm{~g} / \mathrm{m}^{2} /$ day (dry weight), whereas the microalgae in small and medium-sized enterprises on the Atlantic coast produce around $10 \mathrm{~g} / \mathrm{m}^{2} /$ day. Additionally, aqueous cultures in marine water offer the advantage of using land unsuitable for food crops, avoiding the much-publicised dilemma between bod and fuel'. Other differences between land plants and microalgae that could give microalgae the advantage include the possibility of performing continuous cultures in photobioreactors with a high level of control, the potential to couple microalgal production with the disposal of effluents that provide nutritive components, the attractive idea of using industrial $\mathrm{CO}_{2}$ sources, and the saving of freshwater by cultivation of microalgae in seawater. The opportunity to cultivate in photobioreactors offers the additional possibility of adjusting and adapting culture conditions in real time, allowing growers to react instantaneously to the culture situation. The biological diversity of microalgae provides an exceptional range of adaptability and represents a vast potential as a source of food and feed, biomaterial, original molecules and applications in the broad field of biotechnology. Gene transfer of the means to produce selected molecules by genetic engineering will provide a complementary production method for novel compounds.

\subsection{Applications of microalgae}

The current and forthcoming applications of microalgae are numerous and diverse, including food, feed, healthcare, industry and energy. Although the use of cyanobacteria in food dates back many hundreds of years, advances in this area were made in the 20th century (Habib et al., 2008). The market for microalgae as food and food supplements is dominated by the Cyanobacteria Spirulina platensis (also called Arthrospira platensis), the Chlorophyta Chlorella sp., and in France, the diatom Odontella aurita. In addition, the green microalga Dunaliella salina is used for its beta-carotene, Haematococcus pluvialis for astaxanthin and the Cyanobacteria Aphanizomenon flos-aquae as a dietary supplement. Investigation is still needed on the use of other microalgae as food, requiring effort to be made for the acceptance of these alternative sources. For example, cookies made from the Haptophyta Isochrysis galbana, rich in omega-3, have already been produced (Gouveia et al., 2008).

The area in which microalgae were first mass produced was aquaculture. Phytoplanktonic organisms are an essential food for the rearing of molluscs and fish, especially to feed the early life stages of bivalves, for which microalgae must be provided as live food. A large production capacity is devoted to this activity worldwide. Although around 40 microalgal species are used in this way, the number routinely grown is closer to a dozen. The technology and skills developed as part of this culture are important for the future of microalgal biotechnology. Microalgae could become an important source of land animal feed. The most common species used for this are Spirulina, Chlorella and Scenedesmus. In chicken farming, it is reported that the incorporation of 5 to $10 \%$ microalgae in the diet has an effect on the colour of the meat and egg yolk (Becker, 2007). The potential substitution of fish oil with algae oil has also been discussed (AbuGhazaleh et al., 2009).

Algae also offer several benefits in the field of human healthcare. Land plants and animals lack the enzymes to synthesise polyunsaturated fatty acids (PUFAs) longer than 18 carbon atoms. Long-chain PUFAs like gamma-linolenic (GLA), arachidonic (AA), eicosapentaenoic (EPA) and docosahexaenoic acid (DHA), produced by microalgae, accumulate in most marine animals. Sufficient consumption of such fatty acids could have beneficial effects on human health. The oil from the stramenopile Schizochytrium $s p$. (permitted as a food ingredient) contains 35-45\% DHA. In comparison, most conventional oils rich in omega-3 (walnut oil, canola oil) contain about $10 \%$ alpha-linolenic acid, the precursor of omega- 3 . The production of these PUFAs will undoubtedly be a major challenge in the coming years. 
Algal pigments, such as carotenoids, are already commercially exploited but are also the subject of intensive research. The most popular among these are beta-carotene, alphacarotene, lutein, lycopene and zeaxanthin. Even though the main supply of astaxanthin to colour salmon is $95 \%$ of synthetic origin, natural sources such as the green microalga Haematococcus pluvialis are authorised in Japan and Canada (Lorenz and Cysewski, 2000). Among other marine pigments of interest, the phycobiliproteins are a very unusual class identified in microalgae. First commercialised in clinical and immunological analysis, broader uses in industry and therapy are envisioned (Sekar and Chandramohan, 2008).

The uptake of oxygen by organisms can cause the formation of dangerous derivatives, including singlet oxygen and free radicals. These forms of highly reactive oxygen species (ROS) play an important role in various chronic diseases (cancer, atherosclerosis, osteoarthritis, Parkinson's, etc.) or acute reactions (inflammation, septic shock, etc.). However, ROS production can also be used as a means of therapy in human health. Indeed, photo-dynamic therapy (PDT) is an innovative discipline calling for photosensitive molecules with a tumour tropism that react to light and destroy the surrounding tissues by ROS production. Only a few drugs are presently in use for PDT. Less than a dozen molecules have been identified so far and none are, as yet, considered very efficient. It is, however, a promising field as our laboratory was able to identify a group of molecules from microalgae that is 30 times more efficient than the best commercial gold standard (Unpublished work, Patrice, T., Cadoret, J. P., Picot, L., Kaas, R. and Berard, J. B.).

The polysaccharides extracted from the red microalga Porphyridium purpureum have been proven to have antiviral activity on cell lines, as well as in vivo in rabbits (Huheihel et al., 2002). Indeed, red algae have been studied for their polysaccharide contents both for health (Matsui et al., 2003) and industry applications (Gourdon et al., 2008). Apart from structural polysaccharides, some microalgae synthesise exopolysaccharides. These polymeric compounds form a hydrophilic and polyanionic matrix, retain water and trap cations, allowing the microalgae to resist desiccation. These properties suggest that the algae could be useful for biotechnological applications in environmental fields, through the detoxification of biotopes polluted by heavy metals $(\mathrm{Pb}, \mathrm{As}, \mathrm{Hg}, \mathrm{Cd})$ and in the recovery of some metals such as gold and uranium. The physicochemical characteristics of polysaccharides-particularly their rheological, lubricant and flocculent properties-have been suggested for various applications.

A few hundred microalgae are classified as dangerous due to their toxin production. Among the 90 recorded species, 70 belong to the dinoflagellate group. The potential applications of these toxins in human healthcare have been reviewed by Camacho et al. (2006). Characteristics such as the antifouling properties of microalgae could be exploited produce a range of biogenic' products (Bhadury and Wright, 2004).

Some algal extracts are considered emollients, and are incorporated into anti-aging creams to prevent wrinkles and stimulate collagen synthesis; their ultraviolet (UV) protection properties are also being researched. Although many of the marketing claims about algal bioproducts still need to be proven, business prospects justify the interest shown in this field. Arthrospira and Chlorella, are again those involved in the anti-aging and regenerative products (Spolaore et al., 2006). However, while many applications of microalgae are already in existence, genomics is opening up still more opportunities.

\subsection{Genomics and microalgae}

The rise of next-generation sequencing (NGS) technologies, accompanied by a sharp fall in their cost, has led to the acquisition of important genomic data on microalgae since the 1990s. The pace of the availability of microbial genomes is obviously increasing with NGS technologies, and in addition to the 14 nuclear genomes available (see chapter II and III of 
this volume for a review), the gene repertoire of many additional species is now available through transcriptomics, as discussed below. Due to its phylogenetic proximity to land plants and because many molecular tools are available, the Chlorophyta Chlamydomonas reinhardtii was chosen as a model among photosynthetic organisms and the sequencing of its entire nuclear genome completed in 2007 (Merchant et al., 2007). Comparative phylogenomic analyses have provided insight into the evolution of plants and animals, allowing genes to be associated with photosynthesis and flagellar functions, and links established between ciliopathy and the composition and function of flagellae. Over the past decade, many post-genomics and genetic tools have been used on this species, including microarrays, antibodies, RNAi and genetic transformation. These approaches have enabled the exploration of metabolic pathways and biological processes such as responses to stress, the circadian clock (Matsuo and Ishiura, 2011), photosynthetic electron transport chains (Hermsmeier et al., 1994), mechanisms of carbon concentration (Yamano and Fukuzawa, 2009) and flagellar assembly (lomini et al., 2009). In addition, proteomic studies have provided major research contributions in the areas of photosynthesis, molecular biology and evolution (Rolland et al., 2009, Muhlhaus et al., 2011). The other alga species sequenced were chosen due to their ecological role, phylogenetic distribution or harmful nature. Sequencing provided extensive information on the evolution of these species, helped to identify metabolic pathways and specific genes and clarified processes involved in the cycles of iron, calcium, silica, urea and nitrogen. In addition, sequence data provide essential references for matching with post-genomic investigations, including transcriptomic and proteomic analyses.

The gene content of microalgae is only beginning to be explored. Microalgal genomes can be structurally complex and sizes range from $12.6 \mathrm{Mbp}$ for the Chlorophyta Ostreococcus tauri and $168 \mathrm{Mbp}$ for the Haptophyta Emiliania huxleyi to an estimated 10,000 Mbp for the Dinophyta Karenia brevis (see chapter XI for a discussion of genome size variations in algae). These large genome sizes can preclude full-genome sequencing, thus enforcing the use of transcriptome sequencing to build gene catalogues. Many authors have made this choice, although aware of the risk of neglecting non-transcribed sequences. Among the species studied in this way, we can mention the Ochrophyta Pseudochattonella farcimen, which is associated with fish mortalities (Dittami et al., 2011), green microalgae Chlorella vulgaris UTEX 395 (Guarnieri et al., 2011), Dunaliella salina (Zhao et al., 2011) and D. tertiolecta (Rismani-Yazdi et al., 2011) and the coccolithophore Emiliania huxleyi (Von Dassow et al., 2009). Transcriptomic data have been used for phylogenomics and opened the way for functional post-genomics approaches to the study of physiology, environmental adaptation, life cycles, metabolism and signal transduction pathways. Several major projects for transcriptome sequencing are currently underway (Table 1). One example is the Marine Microbial Eukaryotic Transcriptome Project', which aims to sequence the transcriptomes of approximately 750 samples expected to represent hundreds of species and strains with key ecological roles and evolutionary importance in the tree of microeukaryotes (http://marinemicroeukaryotes.org/). To date, 39 microbial algal transcriptomes have been sequenced (Table 1). In order to establish a reference database from ecologically and phylogenetically relevant photosynthetic protists for the Tara Oceans expedition', the Prometheus project' is proposing to sequence about $\overline{30}$ species of ecological or $\overline{\bar{p}}$ hylogenetic importance (http://oceans.taraexpeditions.org) (Karsenti et al., 2011).

We can therefore hope, in a few months or years, to have a very large number of new transcriptomic and genomic data for algae. The development of genomics has already made a major contribution to fundamental research on photosynthetic eukaryotes in the fields of functional biology, global ecology and the evolution of organisms. These data will accelerate the commercialisation of alga-derived compounds by providing a framework for hypothesisbased strain improvement programs built on an improved fundamental understanding of the specific pathways and regulation of networks. These studies are also the source of new biotechnologies that will be presented in the following sections. 


\section{Biotechnology and microalgae}

For 2011, a search using the two keywords microalgae' and biotechnology returned 51 publications in Web of Science database. More than a third of these were on energy and biofuels. In second position, with $20 \%$ of the papers, came work on different cultivation and extraction techniques. Cell factories, i.e., the production of recombinant proteins, came in third position, with a number of technical advances in Chlamydomonas sp.

\subsection{Microalgal Lipids as Biofuel and Food}

\subsubsection{Algal lipid synthesis: The contribution of genomic data}

Compared with land plants, the lipid composition of algae shows great specificity, such as the presence of long-chain PUFAs or the species-specific absence of phosphatidylcholine and phosphatidylserine in the membranes, replaced by diacylglyceryltrimethylhomoserine (DGTS) (Guschina and Harwood, 2006). In addition, for many algal species, high-energy reserves of triacylglycerol (TAG) accumulate in large amounts in lipid droplets in response to different types of stress or nutrient deficiency. TAG represent $>50 \%$ of the algal dry weight and serve for membrane synthesis or carbon storage (Hu et al., 2008), making it possible to obtain oil yields 10 times higher per hectare than with land plant species. Recent soaring oil prices, diminishing world reserves and the environmental damage associated with fossil fuel consumption have led to increased interest in using algae as an alternative and renewable feedstock for fuel production. The development of the microalgal biodiesel industry depends primarily on the reduction of production costs, and one strategy to achieve this is to increase lipid productivity. This explains the large investment being placed in such technology, and demonstrates why most genomics work on algae is aimed at describing and orienting their lipid metabolism (Norsker et al., 2011).

Many studies have been conducted on land plants to understand their mechanisms of lipid synthesis and the development of reserves in their seeds. It was reported that environmental conditions (nutrients, salinity, light, etc.) affect microalgal fatty acid accumulation (for a review, see Hu et al., 2008). However, molecular mechanisms that trigger and control the accumulation of storage lipids in microalgae are poorly understood. Genomic data have allowed the identification of new enzymes and helped to show how lipid pathways interrelate with energy and carbohydrate metabolism (Wallis and Browse, 2010). Until recently, the molecular mechanisms involved in regulatory pathways in algae were still poorly understood. With genomic data and genetic tools available for the green microalga Chlamydomonas reinhardtii, lipid metabolism has been mainly studied in this species and overviews of these findings can be found in several papers (Guschina and Harwood, 2006, Khozin-Goldberg and Cohen, 2011, Moellering and Benning, 2010). Many genes of C. reinhardtii involved in fatty acids and TAG metabolism have been identified based on their orthological relationships to fungi and land plants. In green microalgae, starch synthesis shares common carbon precursors with lipid synthesis. In C. reinhardtii, it has been shown that shunting of carbon precursors from the starch synthesis pathway may facilitate carbon partitioning into the fatty acid synthesis pathway resulting in enhanced production of TAG (Li et al., 2010b). Identification of genes and biosynthetic pathways implicated in lipid biosynthesis is usually made using starchless mutants. With regard to the metabolism of TAGs, genomic data have shown conservation of the main biosynthetic pathways between microalgae and seed plants. Briefly, fatty acids are synthesised in the chloroplasts, in which acetyl-CoA carboxylase (ACCase) provides the malonyl-CoA substrate for the biosynthesis of fatty acids thanks to the fatty acid synthase, a multifunctional enzymatic complex (Guschina and Harwood, 2006). Free fatty acids are then either used for the synthesis of membrane lipids or exported to the endoplasmic reticulum for the biosynthesis of TAGs. This synthesis involves the sequential 
transfer of acyl groups from acyl-CoA to different positions of glycerol-3-phosphate. Most acyltransferases and a phosphatases involved have been identified in the genome of $C$. reinhardtii (Merchant et al., 2011). Nevertheless, significant differences from land plants were observed in the TAG pathways of $C$. reinhardtii, such as the absence of the extra-plastidic lysophosphatidyl acyltransferase in the genome and the presence of new enzymes that are, as yet, poorly characterised ( $\mathrm{Hu}$ et al. 2008). Most recently, an alternative chloroplast pathway of TAG synthesis was identified in C. reinhardtii (Fan et al., 2011). TAG accumulates in lipid droplets, in which proteomics techniques revealed the importance of a major lipid droplet protein (MLDP). Miller et al. (2010) used 454 and Illumina technologies for transcriptomic analysis, and showed how nitrogen deprivation redirects lipid metabolism. In brief, genomic and post-genomic data have allowed lipid metabolism pathways and regulation to be characterised in the Chlorophyta $C$. reinhardtii. However, this alga is not an oleaginous species. With the great diversity that exists among algae, specific studies are now being conducted on lipid-accumulating species in numerous laboratories around the world.

\subsubsection{Algal lipids as biofuel}

Very recently, several studies have used post-genomics to study the lipid metabolism of high oil-content algae. This illustrates a real drive in the exploration of the functional metabolism of oleaginous algae. In 2011, Rismani-Yazdi et al. (2011) published the NGS and transcriptome annotation of a non-model member of the Chlorophyta: Dunaliella tertiolecta. Genes encoding key enzymes were identified by homology and metabolic pathways involved in the biosynthesis and catabolism of fatty acids, TAG and starch were reconstructed (Rismani-Yazdi et al., 2011). A few months later, similar work was reported in a strain of the oil-producing green alga Botryococcus braunii (Baba et al., 2011). In parallel, proteomic approaches have identified new proteins involved in the storage of TAG in the lipid droplets of the Chlorophyta Haematococcus pluvialis (Peled et al., 2011). Guarnieri et al. (2011) reported a comprehensive proteomic and transcriptomic investigation of lipid accumulation in the unsequenced green alga Chlorella vulgaris UTEX 395. The authors presented the first utilisation of a de novo assembled transcriptome as a search model for proteomic analysis. The regulation of fatty acid and TAG biosynthetic pathways was analysed under nitrogen limitation. This oleaginous species is extensively studied due to its relatively fast growth rate, its value as both a food supplement and a potential biofuel feedstock and its ability to produce high-economic value molecules and to remediate heavy metals from wastewater. For these reasons, the genome of the Chlorophyta Chlorella variabilis NC64A was previously sequenced by Blanc et al. (2010). However, difficulties were encountered in identifying proteins by comparing data with strains of species from the same phylum. The researchers pointed out the importance of having unique sequence data to study species and strains of interest (Guarnieri et al., 2011).

Although lipid biosynthesis pathways have been studied in several species, very few studies focus on the regulation of these pathways. Given the induction of TAG biosynthesis by different stresses, it is likely that the mechanisms for the regulation of TAG synthesis differ between algae and seed plants, as the latter produce oil during a specific phase of their life cycle and in specialised tissues. The means of regulation are presently of great interest, as these are the key to engineering algal crop production without causing weakening through nutrient stress. Although transcriptomics offer a wealth of information on gene expression, the processes of mRNA splicing, ribosome recruitment and post-translational regulations of proteins are not well understood in algae and transcriptomic analysis does not adequately define the control points for metabolic regulation.

By providing insight into the mechanisms underpinning lipid metabolic processes, results can be of use for the genetic manipulation of organisms to enhance the production of feedstock 
for commercial microalgal biofuels. By 1996, Dunahay and co-authors were able to overexpress ACCase in the diatom Cyclotella cryptica, which is a key enzyme in the biosynthesis of fatty acids (Dunahay et al., 1996). However, no increase in the amount of lipid was observed. In expressing recombinant thioesterases to enhance the expression of shorter chain length fatty acids, Radakovits et al. (2010) were able to improve the level of lauric and myristic acids in the diatom Phaeodactylum tricornutum. This creates an advantage for biofuel feedstock because biodiesel made from saturated short or medium chain length fatty acids has a relatively low cloud point and is resistant to oxidation. In addition, several studies have shown metabolic shifts in starchless mutants of Chlamydomonas reinhardtii in favour of an overexpression of TAG (Moellering et al., 2009, Wang et al., 2009, Li et al., 2010a). In a starchless mutant, Moellering et al. (2009) inhibited the expression of MLDPs by RNAi, which increased the size of the lipid globules (Moellering et al., 2010) but also resulted in decreased growth. In contrast, the fatty acid content of a starchless selected mutant of Chlorella pyrenoidosa was doubled without detriment to its growth characteristics (Ramazanov and Ramazanov, 2006). This suggests that it is possible to improve the productivity of microalgae using lipid selection strategies. To date, the genomic data available on the selected species is still patchy, and reverse genetic tools are completely absent in these species. We also lack genetic information on the molecular mechanisms leading to these beneficial mutations. The exponential increase of genomic and post-genomic technology should enable biologists to acquire data, and reverse genetic tools should improve our understanding of the metabolism of these lipids and demonstrate ways in which these processes can be improved.

Recently, we put one of the first varietal selection strategies into action in our laboratory. We used successive rounds of UV mutation and cell sorting to improve the TAG production of the Haptophyta Isochrysis galbana affinis Tahiti (a strain related to the Isochrysis galbana strain), a species that offers numerous advantages for lipid production. This approach, which does not create genetically modified organisms (GMOs), allowed us to obtain a strain that accumulates twice the amount of neutral lipids as the original without affecting the growth rate (Rouxel et al., 2011).This strategy quickly improved the performance of an unsequenced selected species, so similar strategies will now be tried on other species and other valuable molecules. From now on, the acquisition of transcriptomic and proteomic data will be used to identify genes and molecular processes involved in the increase of lipid accumulation.

\subsubsection{Algal lipids as feed and food}

Apart from the high importance of TAG from algae, the identification of enzymes involved in the synthesis of PUFAs, such as the long-chain PUFAs AA, EPA and DHA, is of great interest due to the health benefits they offer. Production of PUFAs involves a consecutive series of desaturations and elongations of the fatty acyl chain. Until recently, numerous authors isolated and characterised lipid metabolism and enzymes using biochemical technologies. These studies are reported in a review by Guschina and Harwood (Guschina and Harwood, 2006). Over the last few years, authors have used genomic data to understand the biosynthetic pathways of PUFAs. Because of the putative role of PUFAs in the virulence of the fish pathogen Pseudochattonella farcimen, Dittami and co-authors analysed the expressed sequence tags (ESTs) of this species. Focusing their attention on PUFA metabolic pathways, they identified new specific desaturases related to this virulence (Dittami et al., 2011). In the same way, the ESTs of Myrmecia incisa, a green coccoid freshwater microalga rich in AA, were analysed and a putative new elongase was identified (Yu et al., 2011). Pan et al. (2011) sequenced the genome of the high PUFA-content species of Heterokonta Nannochloropsis oceanica using next-generation Illumina sequencing technologies. Sequence similarity-based investigation identified new elongase- and desaturase-encoding genes involved in the biosynthesis of long-chain PUFAs, which provide the genetic basis of its rich EPA content. 
To date, major lipid primary metabolism has been well studied in model species, but regulation pathways, catabolism and secondary metabolic pathways of lipids are complex and rarely studied. Many metabolites of lipids have high biotechnological potential. The control of lipid metabolism, which is highly regulated, is of great interest as a means of increasing the lipid yields in culture. Furthermore, strategies using random mutations and strain selection have succeeded in increasing the lipid content of selected strains, but without a clear understanding of the mechanisms involved. This demonstrates that there are still many gaps in the knowledge that would help us to optimise lipid production from algae. Genomic and post-genomic studies on a variety of microalgae will provide the basis for identifying metabolic and signalling pathways.

\subsection{Bioactive Natural Products}

Commercial applications of microalgae include their use as natural sources of valuable macromolecules, such as carotenoids and phycocolloids. Due to the exceptionally high diversity of the different groups and the low level of exploration carried out so far, algae are a burgeoning reservoir of high added-value compounds. During the last decade, full genome analysis unveiled numerous new natural products in bacteria and fungi. Indeed, it appears that many of their genomes contain more gene clusters coding for the biosynthesis of natural products than natural products isolated from these same species (Winter et al., 2011). Similar results have been observed in microalgae. For example, in silico analysis of the Heterokonta Aureococcus anophagefferens genome revealed the presence of five berberine bridge enzymes involved in the synthesis of toxic isoquinoline alkaloids, although this type of alkaloid had never been previously identified in this harmful species (Gobler et al., 2011). Genomic exploration of microalgae appears to be a promising way to discover new bioactive products. To date, the analysis of available genomes has aided the identification of pathways to known compounds, thereby greatly facilitating regulatory and functional investigations. The search for enzymes involved in the biosynthesis of polyketides, isoprenoids, non-ribosomal peptides, oxylipins and alkaloids was conducted in silico by looking for homologous genes of land plants in sequenced genomes of microalgae (for review, see Sasso et al., 2011). Although some pathways have been elucidated, there are still many gaps in our knowledge of the metabolism of the secondary metabolites. For example, isoprenoids comprise numerous bioactive molecules such as sterols, phytohormones, phytol, prenylated quinones and carotenoids, which have numerous qualities of interest for biotechnology. While the common first steps of the synthesis of isoprenoid compounds have been well described (Lohr et al., 2012), very little is known about the biosynthesis of secondary isoprenoids except for the carotenoids. The genetic basis of the biosynthetic pathways of sterols and carotenoids in algae has been examined in detail by phylogenomics across several phyla of algae in order to gain insight into the evolution and diversity of photosynthetic eukaryotes (Frommolt et al., 2008, Cui et al., 2011, Desmond and Gribaldo, 2009) (see chapter II, III and IV of this volume). This has led to the identification of genes in organisms where pathways had not been identified before and demonstrated the steps by which more new enzymes could be discovered. The induction and regulation of astaxanthin and carotenoid biosynthesis in Chlorophyta such as Sphaerella lacustris or $D$. salina has received considerable attention owing to the increasing use of secondary carotenoids as a source of pigmentation for fish in aquaculture, and their potential as free-radical quenching drugs in cancer prevention. In aiming to identify the proteins involved in the regulation and biosynthesis of astaxanthin, comparative proteomics and transcriptomics were applied to the chlorophytes Haematococcus pluvialis and H. lacustris (re-named Sphaerella lacustris) under nitrogen starvation and irradiance stress (Kimet al., 2006, Eom et al., 2005, Tran et al., 2009a), and the regulated genes identified. These genes putatively play a role in signal transduction from stress to the cellular defence system and activate the biosynthesis of astaxanthin. Complementary in-depth analysis should confirm the significance of these results. These genes include potential targets to increase the expression of astaxanthin. 
Overall, it is clear that our understanding of secondary metabolism and its regulation is still rudimentary. Secondary metabolites include a large number of natural bioactive products, many of which are unknown. In silico genome analyses are a key to the identification of new metabolic and signalling pathways. Post-genomics can be applied to identify physiological conditions that lead the expression of new pathways, and so identify hitherto undetected metabolites.

\subsection{Molecular Farming}

The extraction of natural substances remains the main source of supply for a large number of pharmaceutical molecules. However, since it is possible to identify the genes responsible for building a protein molecule, they can be introduced into cultured cells, which then become cell factories, making millions of copies of the desired product. This strategy-the expression of molecules with high added value in recombinant cell systems-offers extraordinary opportunities for the development of a very promising biotechnology market (estimated to be worth up to several tens of billions of dollars, depending on the information source) (Schmidt 2004, Gasdaska et al. 2003). The production systems available are bacteria, yeasts and animal or plant cells, which are genetically modified to produce insulin, growth hormones, monoclonal antibodies and other therapeutic proteins. Each system has advantages and disadvantages relating to factors such as cost, production safety, ease of extraction, purification and complexity of producing the molecules. Some solutions, however, combine a number of benefits, putting them in a strong position for the future of this industry.

Microalgae have several advantages over other expression systems for the production of recombinant proteins, such as: (1) a high growth rate (they commonly double their biomass within $24 \mathrm{~h}$ ), (2) easy cultivation at a low production cost (they only require water and nutrients), (3) the possibility of performing post-transcriptional and post-translational modification as in other eukaryotic expression systems and (4) photobioreactor culture methodologies that prevent transgenes from escaping into the environment, which is a potential risk when using land plants (Janssen et al., 2003).

Several interesting reviews on transgenic tools describe the use of microalgae as a platform for production of recombinant proteins (Walker et al., 2005, Hallmann et al., 2007, Bozarth et al., 2009, Potvin and Zhang, 2010). Here, we focus on recent progress and results on transgenic microalgae technology for the production of therapeutic recombinant proteins, and discuss the contribution of genomic studies for the optimisation of genetic manipulation in microalgae.

\subsubsection{Transgenic microalgae as a platform for biopharmaceutical proteins}

In this section, we provide a review of biopharmaceutical proteins expressed in microalgae systems according to their intracellular cell localisation (chloroplastic or nuclear). The interest in the $\mathrm{N}$-glycosylation of pharmaceutical proteins will also be discussed.

Although no recombinant protein produced by transgenic algae is yet available on the market, some therapeutic proteins have been successfully produced using microalgae, mainly the Chlorophyta Chlamydomonas reinhardtii, for which suitable transgenic tools and genomic data are available (for all three genomes: nuclear, chloroplastic and mitochondrial). Mayfield's group has done considerable work on the chloroplastic expression of recombinant protein in C. reinhardtii (Rasala and Mayfield, 2011a). Indeed, the majority of microalgal therapeutic proteins have been produced by chloroplasts (Table 2). Transgenic protein can accumulate to much higher levels in the chloroplast than when expressed by the nuclear genome because plastids lack disadvantages such as gene-silencing mechanisms (Bock, 
2007). Indeed, expression of foreign proteins remains very low for reasons that are not yet fully understood (Potvin and Zhang, 2010). The chloroplast of C. reinhardtii has been used to produce a range of recombinant proteins, including reporters such as glucuronidase (GUS), luciferase (LUC), green fluorescent protein (GFP), industrial enzymes, vaccines and therapeutic enzymes (Rasala and Mayfield, 2011a).

The first therapeutic protein expressed by transgenic microalgae was produced at Mayfield's laboratory using chloroplast transformation in the green microalga $C$. reinhardtii. In the study of Mayfield et al. (2003), the entire IgA (Imunnoglobulin A) heavy chain protein (HSV8-lcs) fused to the variable region of the light chain was expressed and accumulated as a soluble protein able to bind to the herpes virus protein. Nevertheless, the expression yield was too low (detectable only) for commercial use, even though several regulation sequences (promoters) were tested. Regulation sequence aspects will be examined in the next section. This previous study was completed by the chloroplastic expression of a single chain fragment variable antibody (HSV8-scFv) that accumulated to $0.25 \%$ of total soluble protein (TSP) (Mayfield and Franklin, 2005). In their next study, the same team successfully increased the accumulation of a bioactive mammalian protein, bovine mammary-associated serum amyloid A (M-SAA), to $5 \%$ of TSP with by chloroplasts, using different promoter sequences and an interesting strategy consisting of replacing an endogenous gene by the expression cassette (Manuell et al., 2007). Recently, a full-length human monoclonal antibody was expressed in the chloroplast of $C$. reinhardtii, proving that this eukaryotic green alga is capable of synthesising and assembling a full-length antibody in transgenic chloroplasts (Tran et al., 2009b). More recently, a study was conducted to examine the versatility of algal chloroplasts for the expression of seven different therapeutic proteins: human erythropoietin (EPO), the 10th and 14th human fibronectin type III domains (14FN3 and 10FN3), human interferon $\beta 1$, the human vascular endothelial growth factor (VEGF) isoform, the high mobility group protein (HMGB1) and the human proinsulin. Of the seven proteins tested, four were successfully expressed in transgenic chloroplasts to above $2 \%$ of TSP (Rasala et al., 2010). However, no detectable expression was shown for EPO or interferon $\beta 1$. Like Mayfield's group, other research groups have successfully shown that the chloroplast of $C$. reinhardtii is a perfect platform to produce recombinant proteins at an economically viable cost (Zhang et al., 2006, Yang et al., 2006, Wang et al., 2008). In addition to therapeutic proteins, some vaccines have been successfully produced in algal chloroplasts. Indeed, a fusion protein between the foot and mouth disease virus VP1 and the cholera toxin B subunit (as mucosal adjuvant) was reported to accumulate to $3 \%$ of TSP in transgenic algal chloroplasts (Sun et al., 2003). This fusion protein retained both specific ganglioside-binding affinity and antigenic function. A classical swine fever virus (CSFV) E2 recombinant protein was also successfully expressed in chloroplast to around $2 \%$ of TSP and observed to have immunological activity (He et al., 2007). Surzycki et al. (2009) reported a strong expression of the white spot syndrome VP28 protein by chloroplasts to around $10.5 \%$ of TSP. Moreover, in this study, the authors attempted to determine factors affecting the level of recombinant protein expression, which will be covered in the next section. Recently, Dreesen et al. (2010) reported the oral immunisation of mice by transgenic algae expressing (to $0.7 \%$ of TSP) the Staphylococcus aureus fibronectin-binding domain D2 fused to the cholera toxin $B$ subunit.

It is important to reiterate that all these studies were carried out using transgenic chloroplasts of the green algae $C$. reinhardtii. To our knowledge, there are no reports of biopharmaceutical protein expression by transgenic chloroplasts in other microalgae.

Although it is estimated that most of the therapeutic human antibodies used in therapy do not require glycosylation, other therapeutic proteins require the correct glycosylation pattern to function properly (Dove, 2002). Nevertheless, nuclear expression of therapeutic proteins remains limited because of some problems in reducing yield expression (Potvin and Zhang, 
2010). Transgenic microalgal technologies are still in their infancy and the therapeutic proteins expressed by the nuclear genome are still rare in microalgae.

Initial work has been done by Hawkins and Nakamura (1999) to produce human growth hormone in the extracellular medium of Chlorella sorokiniana and C. vulgaris C-27. In a subsequent study, growth hormone of sole was produced and expressed as a stable product in C. ellipsoidea (since renamed Chloroidium ellipsoideum). Soles fed with these transgenic microalgae increased in size by $25 \%$ (Kim et al., 2002). Another research team has shown the efficient expression and biological activity of rabbit neutrophile peptide-1 in $C$. ellipsoideum cells (Chen et al., 2001).

Recently, Dauvillée et al. (2010) expressed a nuclear protein corresponding to the Plasmodium antigens that fuse to granule-bound starch synthase (GBSS), a protein involved in the starch matrix of plants and algae. The C-terminal domains from apical major antigen (AMA1) or major surface protein (MSP1) fused to GBSS were both efficiently expressed in nuclear cells and targeted starch particles in the chloroplasts, taking advantage of the transit peptide on the GBSS protein. Although expressed in the nucleus, these fusion proteins directly targeted starch granules, avoiding post-translation modification such as $\mathrm{N}$ glycosylation. Immunogenicity tests for both fusion proteins were successfully performed in mice (Dauvillee et al., 2010).

More recently, diatoms have also been used as cell factories to produce recombinant proteins. Diatoms are an algal group of great ecological importance. Their contribution to global $\mathrm{CO}_{2}$ fixation represents around $40 \%$ of marine carbon production. Diatoms like Phaeodactylum tricornutum represent an interesting subject for a variety of biotechnological applications, and this species has become a model organism for the diatoms (Bowler et al., 2008, Siaut et al., 2007, Hempel et al., 2011a and b). Indeed, its whole genome has been sequenced and molecular tools for functional genomics are available (Maheswari et al., 2009, Siaut et al., 2011). To date, diatoms have not been employed for expression of any biopharmaceutical proteins, but a research team has recently reported the first stable expression of a full-length human antibody and the respective antigen in $P$. tricornutum (Hempel et al., 2011b). In this study, the antibody and respective antigen were both expressed and accumulated within the endoplasmic reticulum (ER) using the ER retention signal. Interestingly, while the same expression vector and molecular tools were used for the expression of both these recombinant proteins, different expression levels were observed for the antibody ( $7.8 \%$ of TSP) and antigen ( $0.7 \%$ of TSP). This result confirms that not all foreign proteins are equally expressed (Potvin and Zhang, 2010).

At our laboratory, we became interested by the potential of microalgae as a means to produce therapeutic proteins (Cadoret et al., 2008). This interest led to the creation of a private company by our laboratory: Algenics. Algenics is the first privately owned European biotechnology company focusing on innovative uses of microalgae to produce recombinant biotherapeutics. Using microalgae as a platform for recombinant proteins, our laboratory filed a patent on the production of glycosylated proteins in microalgae (Cadoret et al., 2009). Recently, as proof of the concept, we successfully produced another therapeutic protein, murine erythropoietin (mEPO), in the diatom P. tricornutum (Unpublished work, Carlier, A., Bardor, M., Lerouge, P., Delavault, P., Saint-Jean, B., Gerard, A., and Cadoret, J.P.). The data show that recombinant mEPO accumulates to around of $0.05 \%$ of TSP (or $300 \mu \mathrm{g} / \mathrm{L}$ ). This recombinant EPO is glycosylated and able to bind the human EPO receptor in vitro with the same affinity. These results, combined with Hempel's data, confirm the high potential of diatoms to express biopharmaceutical proteins.

This last result corroborates the expression specificity of some foreign proteins according to cell localisation and/or algal taxon. Indeed, no detection of recombinant EPO has been reported in Chlorophyta C. reinhardtii transgenic chloroplasts (Rasala et al., 2010). In 
contrast, Eichler-Stahlberg et al. (2009) observed a minor accumulation of recombinant EPO up to around $100 \mu \mathrm{g} / \mathrm{L}$ in nuclear expression by C. reinhardtii cells. Thus, EPO protein accumulates differently and at different expression levels according to cell localisation or species.

To conclude, many efforts have been made to produce biopharmaceutical proteins at a level sufficient to be economically viable, but extensive research to optimise microalgae as cell factories still needs to be done. Recent success in microalgal transgenesis and input from genomic data will allow a response to the growing demand for biopharmaceutical molecules. However, microalgae can also provide compounds other than pharmaceutical proteins. Indeed, an interesting study has recently been reported that used microalgae to produce industrial products such as bioplastic: Hempel and co-workers (2011) expressed three prokaryotic enzyme genes in the diatom $P$. tricornutum to produce poly-3-hydroxybutyrate (PHB). These genes (i.e., a ketolase, an acetoacetyl-CoA reductase and a PHB synthase) are able to synthesise PHB from acetyl-CoA in diatom cells up to a level of $10.6 \%$ of algal dry weight.

Of the post-translational modifications encountered in eukaryotic proteins, $\mathrm{N}$-glycosylation is the most prevalent of those that appear essential for biological functions (biological activity, short half-life). Moreover, glycosylation is of particular interest for biopharmaceutical proteins, since more than $70 \%$ of biopharmaceuticals are glycoproteins. Glycosylation capability is an advantage for any system used to produce biopharmaceuticals. This pathway is currently well understood among the different production systems available today, such as cultured mammalian, yeast and plant cells. Plants have $\mathrm{N}$-glycosylation capability similar to mammalian cells. However, $\mathrm{N}$-glycosylation patterns processed in plant cells differ from those of humans and other mammals. In plants, $\mathrm{N}$-linked glycans contain $\beta(1,2)$-xylose and $\alpha(1,3)$-fucose instead of the $\alpha(1,6)$-fucose found in mammals. These plant-specific glycans are considered to be potentially antigenic and/or allergenic epitopes (Bakker et al., 2001). Several strategies have been studied to remove the antigenic potential of plant-specific glycans. One simple approach is aglycosylation to obtain recombinant protein with no Nglycosylation by mutating the $\mathrm{N}$-glycosylation sites of expressed genes (Conley et al., 2009). This approach is effective if the biological activity is not affected by aglycosylation.

Another approach consists of retaining the foreign protein in the ER using KDEL/HDEL retention signals to avoid plant-specific glycan residues such as $\beta-(1,2)$-xylose and $\alpha-(1,3)$ fucose (Ko et al., 2003, Gomord et al., 2004, Petruccelli et al., 2006). Indeed, glycosylation processing in the ER is conserved between the plant and animal kingdoms and restricted to high mannose-type N-glycans, whereas the further glycosylation process in the Golgi apparatus, where additional glycans are added for glycan maturation, is highly diverse. Another approach to eliminating plant-specific glycan residues is to knock out the gene expression of glycosyltransferases involving $\beta$-(1,2)-xylosylation and $\alpha-(1,3)$-fucosylation (Gomord et al. 2004). However, in addition to eliminating plant-specific sugar, humanisation of $\mathrm{N}$-glycosylation is also essential for the production of authentic glycosylated recombinant proteins in plants. The strategy to humanise plant $\mathrm{N}$-glycans consists of expressing mammalian glycosyltransferases, which would complete $\mathrm{N}$-glycan maturation, in plants (Bakker et al., 2001).

So far, little information regarding the glycosylation of microalgae is available and it is interesting, both from a purely scientific point of view and for biotechnological applications, to determine their capacity for this process. Our laboratory published the first in silico $\mathrm{N}$ glycosylation study in microalgae. Using the genomic data available for $P$. tricornutum, we identified specific genes coding enzymes involved in the $\mathrm{N}$-glycosylation pathway in diatoms (Baiet et al., 2011). Moreover, by structural analyses of $\mathrm{N}$-linked glycans, this study also demonstrated that $P$. tricornutum proteins carry mainly high mannose-type $\mathrm{N}$-glycans. Interestingly, other recent biochemical studies have reported the existence of special 
glycosyltransferase and glycosylation pathways, unique to the red alga Porphyridium $s p$. (Levy-Ontman et al., 2011).

The emergence of genomic data in microalgae will provide the opportunity to perform comparative genomic studies and to dissect biosynthetic pathways such as N-glycosylation.

Recently, we initiated new studies to evaluate the N-glycosylation pathway of microalgae representing different phyla: green and red microalgae, glaucophytes, alveolates, stramenopile and haptophytes. This study will help us to determine how this specific process evolved within the eukaryotes. Moreover, demonstrating that microalgae are a suitable alternative system for the production of biopharmaceuticals requires the demonstration of their N-glycosylation capability.

\subsubsection{Genomic strategies for optimising recombinant protein expression}

In this section, we report three strategies commonly used to optimise recombinant protein accumulation in microalgae.

\subsubsection{Translation optimisation by codon usage bias}

Specific variations in codon usage are often cited as one of the major factors impacting protein expression level. The presence of rare codons that are correlated with low levels of their endogenous tRNA species in the cell can reduce the translation rate of target mRNA. The classical strategy to bypass this problem is to redesign genes to increase their expression level. For this, two approaches have been attempted, both of which require choosing from a vast number of possible DNA sequences. The first approach consists of assigning the most abundant codon of the host of a given amino acid in the target sequence. The second uses translation tables based on the frequency distribution of the codons in an entire genome or for a range of highly expressed genes. This approach was successfully used in Chlamydomonas reinhardtii to improve the expression level of foreign proteins such as GFP in the nucleus (a 5-fold increase) (Fuhrmann et al., 1999) and chloroplasts (increased up to 80-fold) (Franklin et al., 2002). Similar studies using a codon-optimised human antibody gene or luciferase reporter gene confirmed that codon bias plays an important role in protein accumulation in chloroplasts of C. reinhardtii (Mayfield et al., 2003, Mayfield and Schultz, 2004).

The nuclear and chloroplastic genome of $C$. reinhardtii may exhibit different codon bias and thus, adjustment of codons in foreign gene sequences is necessary to obtain a high rate of protein production. To overcome this issue, the codon adaptation index (CAI) is used as a quantitative tool to predict the expression level of transgenes based on their codon usage. Several molecular software programs are available to determine and optimise codon usage. A list of these programs is given in Villalobos et al. (2006).

This approach, which consists of optimising the codon usage of transgenes, was successfully used in the green alga $C$. reinhardtii and diatom Phaeodactylum tricornutum. Specific codon usage is a field that will benefit from the contribution of future microalgal genomic and transcriptomic sequences.

\subsubsection{Identification of promoter sequences}

Genome data is also necessary to identify functional sequences such as promoter, 5' and 3'untranslated region (UTR) sequences that regulate the gene expression rate. These sequences are specific for each gene and microalgal strain. Due to the presence of plastid and nuclear genomes in microalgae, there are different types of promoter sequences according to cell localisation. Plastid transgenes are expressed under the control of an 
endogenous promoter and $5^{\prime}$ and $3^{\prime}-\mathrm{UTR}$. Overall, promoter sequence control transcription and 5'-UTR mediate mRNA stability, and translation initiation and $3^{\prime}-\mathrm{UTR}^{\prime}$ regulate stability and act in the termination of transcription. The same sequences were found for nuclear promoters, but other regulated sequences such as intron sequences are also involved in the regulation of nuclear gene expression. Previous studies identified sequences within the 5UTR that were involved in RNA stability and used as a means to increase recombinant protein synthesis. For a comprehensive review of chloroplast translation regulation, see Marin-Navarro et al. (2007).

Concerning chloroplastic transformation in microalgae, the green alga C. reinhardtii has been intensively studied. Among chloroplastic promoters for the expression of foreign proteins (Table 3), the endogenous atpA, $p s b D, r b c L$ and $p s b A$ promoters are generally used (Hallmann et al., 2007, Specht et al., 2010). An excellent study performed by Barnes et al. (2005) reported the effect of various promoters and UTRs on recombinant proteins in the chloroplast of $C$. reinhardtii. Using different combinations of chimeric proteins corresponding to the promoters and 5'-UTRs of chloroplast genes, atpA, rbcL, psbA, psbD and 16S rRNA, fused to the GFP reporter and followed by 3'-UTR of either gene, they observed different protein accumulation levels. Moreover, they showed that mRNA accumulation is, in general, proportional to protein accumulation. Also, according to chimeric construction, they observed that the 5-UTR sequence had a significant impact on recombinant protein production while 3 -UTR had little effect. The highest level of reporter protein was found using the atpA or $p s b D$ promoter and 5'-UTR, while a minor protein accumulation level was observed under control of $r b c L$ and $p s b A$ and no expression was seen using the 16S rRNA promoter and 5'UTR (Barnes et al., 2005).

Interestingly, the psbA promoter fused with its 5'-UTR was actually the most used (Manuell et al., 2007, Surzycki et al., 2009). Recently, Rasala et al. (2011b) reported a high recombinant protein expression level with the $p s b A$ promoter in comparison to the levels reached with the atp $A$ promoter. It remains unclear why certain regulatory elements induce a high expression level in some genes but not in others (Marin-Navarro et al., 2007). The psbA promoter and 5'UTR are the most studied, but essentially require a $p s b A$-deficient genetic background for high foreign protein accumulation (Rasala and Mayfield, 2011a).

Other exogenous promoter sequences have been used in $C$. reinhardtii chloroplasts. Kato et al. (2007) showed the functionality of the inducible system of the lac operon of Escherichia coli in C. reinhardtii chloroplasts. At the same time, a riboswitch was reported to act as a translational regulatory factor in C. reinhardtii (Croft et al., 2007). Finally, all the data suggest that the translation mechanism and mRNA accumulation are primarily controlled by the promoter and 5'-UTR, and that the choice of these sequences is a critical factor to consider for each protein of interest in order to achieve high yields of recombinant proteins. On the other hand, to our knowledge, no chloroplast transformation has been reported for microalgae other than $C$. reinhardtii and the unicellular flagellate protist Euglena gracilis, leaving the way open for research to study this mechanism of expression in other microalgae.

Concerning nuclear promoters, several studies have been performed in different taxa of microalgae using endogenous, exogenous and synthetic promoters (Table 3). The most widely used constitutive promoter in the chlorophyte group is RbcS (RuBisCO small subunit). Interestingly, some endogenous promoters of $C$. reinhardtii can be used in other Chlorophyta algae. Indeed, the $C$. reinhardtii $R b c S$ promoter has been successfully used in the green alga Dunaliella salina (Sun et al., 2005), Chloroidium ellipsoideum formerly Chlorella ellipsoidea (Kim et al., 2002), the Heterokonta Nannochloropsis oculata (Chen et al., 2008, Li et al., 2008a) and the Chlorarachniophyta Lotharella amoebiformis (Hirakawa et al., 2008). A chimeric promoter using heat shock protein A (HSP70A) fused to $p s a D$ was also successfully used in C. reinhardtii (Fischer and Rochaix, 2001, Schroda et al., 2000), and more recently in 
the multicellular alga Gonium pectorale (Lerche and Hallmann, 2009). The same strategy, using HSP70 fused to CAb (chlorophyll-binding protein), was reported in the charophyte Closterium peracerosum (Abe et al., 2011). Usual plant promoters, such as the cauliflower mosaic virus $35 S$ with Ubiquitin- $\Omega$, have been also tested in some microalgae (Kumar et al., 2004, Jarvis and Brown, 1991, Chen et al., 2001, Wang et al., 2007), and recently the 35 S promoter demonstrated efficiency in the diatom P. tricornutum (Sakaue et al., 2008), Chlorophytes Haematococcus sp. (Kathiresan et al., 2009) and Dunaliella bardawil (Anila et al., 2011) and the Heterokonta Nannochloropsis sp. (Cha et al., 2011a). Moreover, inducible promoters have been chosen for some algae. Indeed, the gene expression under the control of the nitrate reductase promoter is switched off when cells are grown in the presence of ammonium, and becomes switched on when cells are transferred to a medium containing nitrate. This approach was reported for the diatom Cylindrotheca fusiformis (Poulsen and Kroger, 2005) and recently in Chlorella vulgaris (strain not reported) using the NR cassette (promoter and 5' and 3'-UTR of nitrate reductase) of the diatom Phaeodactylum tricornutum (Niu et al., 2011). A similar strategy was applied in $P$. tricornutum using the endogenous $N R$ cassette (Hempel et al., 2011a, Hempel et al., 2011b) and exogenous NR cassette from the diatom Cylindrotheca fusiformis (Miyagawa et al., 2009). Miyagawa-Yamaguchi et al. (2011) reported the same approach in another diatom, Chaetoceros sp., using the NR cassette of the diatom Thalassiosira pseudonana. The study performed by Niu et al. (2011) is particularly interesting as the diatom $N R$ cassette was shown to be functional in green algae, suggesting that this type of inducible promoter could be universally employed across diverse species of algae.

In contrast to plastid promoters, several studies have been performed on nuclear promoters in diatoms. So far, unlike in green algae, the RuBisCO small subunit gene of diatoms is encoded by the chloroplast genome, and its promoter is not adapted for nuclear transformation. Other promoters were identified from genomic and transcriptomic data from diatoms. Early studies reported protein expression using the acetyCoA carboxylase (Acc1) promoter in diatoms Cyclotella cryptica and Navicula saprophila (Dunahay et al., 1995). Members of the family of light-inducible fucoxanthin chlorophyll $(F C P)$ promoters have also been used to produce foreign protein in diatoms $P$. tricornutum (Apt et al., 1996, Falciatore et al., 1999, Zaslavskaia and Lippmeier, 2000) and Thalassiosira sp. (Falciatore et al., 1999, Poulsen et al., 2006). In contrast to the NR promoter, the Fcp promoter appears to be more specific to the host as, for example, the $F_{c p}$ promoter of $P$. tricornutum is not functional in Cylindrotheca fusiformis (Poulsen and Kroger, 2005).

Some use of virus promoters other than $35 S$ has also been reported in algae, such as mammalian cytomegalovirus CMV in P. tricornutum (Sakaue et al., 2008), and recently in the Chlorophyta Platymonas subcordiformis (Cui et al., 2010), as well as the Rous sarcoma virus in the diatom $P$. tricornutum (Sakaue et al., 2008).

Surprisingly, the use of microalgal virus sequences in algal expression constructs to enhance gene expression has still not been explored. To date, several algal viruses have been identified and their full genomes sequenced in some microalgal taxa, specifically chlorophytes, dinoflagellates, diatoms and haptophytes (for reports and reviews on this topic see, Nagasaki, 2008; Nissimov et al., 2011; Schroeder, Oke, Malin, \& Wilson, 2002; Van Etten \& Dunigan, 2012; Wilson, Van Etten, \& Allen 2009). To date, algal viruses represent a largely unexplored source of genetic elements for engineering algae and land plants. This approach has previously been used in both monocotyledonous and dicotyledonous land plants, as well as in bacteria (Mitra et al., 1994). Another study reported the functionality of a translation enhancer element from the Chlorella virus in the plant Arabidopsis thaliana (Nguyen et al., 2009).

Another strategy to increase the yield of recombinant proteins consists of adding intronic sequences to the expression vector to act as an endogenous enhancer. Indeed, while 
regulation of gene expression occurs at the post-transcriptional level in the plastid, it appears that most regulation occurs both at the transcriptional and translational levels in the nucleus (Marin-Navarro et al., 2007). The introns are non-encoding sequences but can affect the expression of genes by alternative splicing or through the regulation of transcription. In $C$. reinhardtii, Lumbreras et al. (1998) reported that the insertion of endogenous introns from heterologous genes increases the expression level. Recently, a similar approach has been used to increase the expression level of the Renilla-luciferase gene reporter in C. reinhardtii (Eichler-Stahlberg et al., 2009). However, the way in which the introns affect the expression level is still unclear.

\subsubsection{The challenges of transgene silencing and proteolysis}

Transgene silencing is another problem for high-yield recombinant protein expression in plants and algae, but different strategies exist to overcome this obstacle. Indeed, gene silencing can function as a protective system against pathogens or viruses (Specht et al., 2010). Plant virus-encoded suppressors of RNA silencing are useful tools for counteracting silencing, but their wide application in transgenic plants is limited because their expression often causes harmful developmental effects. To our knowledge, this approach has not yet been attempted in microalgae. Recently, another strategy to prevent transgene silencing was reported in Chlamydomonas reinhardtii using a process of UV mutation and selection by antibiotic resistance on a selective medium (Neupert et al., 2009).

To date, most efforts to improve recombinant protein accumulation in plants or algae have focused on increasing protein expression. Moreover, proteolysis is also one of the factors that can affect the yield of recombinant protein accumulated and also lead to difficulties in purification due to degraded forms or non-functional protein (Doran, 2006, Surzycki et al., 2009). However, proteolytic enzymes are essential for the degradation of misfolding or incorrectly processed endogenous proteins. Some strategies have been attempted to minimise foreign protein degradation in plants and microalgae, like producing recombinant proteins in other cell compartments that have an environment with less proteolytic activity. Indeed, for nuclear-expressed protein, the targeting of the ER using the HDEL or KDEL retention signal prevents the degradation of the foreign protein. A similar approach has been successfully used by our laboratory to express recombinant EPO in diatoms. Another approach used in plants consists of concomitantly producing protease inhibitor to neutralise endogenous protease (Doran, 2006).

\section{Future Outlook}

In this chapter, we tried to provide an overview of the principal applications of microalgae and show how genomics and post-genomics can improve their uses in biotechnology. Here, we mainly focused on some of the most popular applications. Without wishing to suggest that they are less important, we chose not to make a detailed review of other applications such as environmental biomarkers, silica synthesis from diatoms or hydrogen and methane production for energy. In any case, the future of microalgal biotechnology will depend on several steps, including domestication and a search for new intrinsic species characteristics, steps for which the contributions of omics' technologies will be invaluable.

\subsection{Domestication}

A strategy comparable to that used for the domestication of crops is now making its way into the world of microalgae. This is a matter of selecting favourable mutations and finding markers that will help select the desired traits. In agriculture, the cross-breeding of species and selection of strains was conducted empirically for thousands of years before Mendel's 
laws provided a scientific basis for species improvement. For sexual reproduction, considerable work remains to be done in microalgae. Knowledge of reproductive strategies is of major importance for maintaining strains, cultivating them on a long term-basis in continuous culture or envisaging selection strategies. Some algal groups have become the subject of increased attention concerning their reproduction strategies and sexual behaviour, including the diatoms (Chepurnov et al., 2011). In the Coccolithophore Emiliania huxleyi, different morphotypes associated with different forms of ploidy have been observed and studied by transcriptomic analysis. This work revealed mechanisms involved in functional differentiation without proving that sexual reproduction occurs (Von Dassow, 2009). To date, there is too little knowledge to envisage the improvement of strains by cross-breeding and selection through sexual reproduction, so future studies in this direction will be of great interest.

Mutation followed by selection for favourable phenotypes has been used for crop plants, and some promising strategies are now beginning to emerge for algae. This domestication route calls for induced mutations and subsequent selection. Bonente et al. (2011) identified the major relevant points for the selection of $\mathrm{H}_{2}$-producing Chlamydomonas sp., namely a reduction of photosynthetic antenna size, an alteration of photosystem II to manipulate the oxygen concentration and a maximised electron flow towards hydrogenase. This strategy was thought to enhance carotenoid levels. Early studies involved Dunaliella salina and the selection of beta-carotene-rich strains (Shaish et al., 1991). These were followed by a search for hyperproductive variants sorted by flow cytometry (Mendoza et al., 2008), and recently there have been improvements in lutein production in the microalga Chlorella sorokiniana (Cordero et al., 2011). This strategy was implemented to enhance overall lipid contents or EPA and DHA, in particular with the Haptophytes Isochrysis galbana (Molina Grima et al., 1995) and Pavlova lutheri (Meireles et al., 2003), the Heterokonta Nannochloropsis oculata (Chaturvedi and Fujita, 2006) or the chlorophyte Dunaliella salina (Mendoza et al., 2008). In this context, the availability of a reliable marker, such as Nile Red or BODIPY for staining lipid bodies, greatly helps in the selection process. In the Haptophyte Isochrysis galbana affinis Tahiti, this strategy allowed our laboratory to select an improved strain that could stably produce twice the amount of TAG compared to its wild-type counterpart (Rouxel et al., 2011).

We have reported that the improvement of microalgae for biotechnology uses will come through the domestication of strains, and this approach has already been initiated. Far from being in conflict, the different approaches (natural' versus GMO') are complementary. Synthetic biology, synthetic genomics and genome engineering are disruptive technologies. Indeed, the development of GMO' strategies is very promising for applications with very high added value such as the production of drugs or antibodies. However, taking into account the environmental risks arising with such transgenic species and societal pressure against their use, their culture will have to be performed in confined and controlled conditions. Their use for energy and food (large outdoor cultures) therefore seems somewhat inappropriate. The completely opposite point of view is that, given the immeasurable biodiversity of algae, the ideal alga for a given application is probably available in nature. Although this perspective is somewhat optimistic, the exploration of biodiversity was the source of the algae presently in use and will doubtless continue to be in the future. Screening this diversity will enable us to identify new, more efficient strains with new features, some of which may have uses that have not yet been imagined. This does not preclude subsequent domestication to improve these species for use in biotechnology.

\subsection{Working towards a new algal metabolism, enzymes and compounds}

As seen earlier in this chapter, the implementation of genomic and post-genomic approaches is now largely underway in the world of microalgae. In parallel, ecological approaches in metagenomics have only been seen very recently. These will hopefully lead to the 
identification of a large number of presently unknown microalgae and, consequently, to new gene networks, enzymes and metabolic pathways. Due to the wide variety of microalgae and difficulties in cultivating certain of them, many metabolic pathways have remained out of our reach until the present. Metagenomics aims to analyse all of the genomic data in a given ecosystem without a strain isolation and cultivation step. This allows access to unknown mechanisms of potential biotechnological interest. In this situation, the sequencing campaigns' on research cruises (Karsenti et al., 2011) will offer new and valuable insight in the field of microalgal genomics. Chapter $\mathrm{XI}$ of this volume provides a review on the power and challenges of metagenomics for microbial algae. Conversely, metagenomics will be greatly aided by new methods like single cell genome analysis (Ebenezer et al., 2011), which can improve methods of isolation and cultivation of new algae.

Among the wide variety of metabolic pathways conceivable across the diversity of microalgae, particular attention should be paid to metabolism from extremes environments. Like bacteria, although to a lesser extent, some microalgal species live under severe physico-chemical pressures such as high salinity, extreme temperatures from below zero to over $50^{\circ} \mathrm{C}$, alkaline or acidic waters or very high irradiance. Additionally, some strains have been isolated downstream from industrial sites such as acid mine drainage, or in waters rich in contaminants such as metals (for review see Das et al., 2009). Extremophiles offer numerous advantages, including: (1) the absence of contaminants in open door cultures subjected to physicochemical pressure; (2) their potential adaptation to industrial environments such as presence of toxins, radioactive elements or extreme $\mathrm{pH}$, and consequently their potential use for the biocatalysis of effluents; and (3) their ability to produce enzymes with biotechnological applications. Proteomics have been carried out to highlight the adaptation mechanisms in the halophilic species Dunaliella salina (Liska, 2004, Katz et al., 2007), for which the genome sequence will soon be available. Transcriptomics and comparative genomics have dealt with the very high biochemical versatility of thermoacidophilic Galdieria sulphuraria (Weber et al., 2004, Barbier et al., 2005). Psychrophilic species have been identified, such as Fragilariopsis cylindrus, Xanthonema sp., Koliella antarctica and Chlamydomonas sp. ICE-L. However, the culture of psychrophiles is far from being technically mastered, making post-genomic approaches difficult. In such cases, metagenomics would be an appropriate solution. Overall, efforts are still needed to isolate and cultivate extremophiles, and genomics will provide a source of new applications.

\subsection{Algal pathogens: Looking towards the future}

Like land plants, phytoplankton are susceptible to diseases and parasitism, which impact their population dynamics and use in commercial industry. Interactions between bacteria and microalgae in the environment and in cultures are numerous, and bacteria can have beneficial or negative effects on the growth of microalgae. For a review, see Fukami et al. (1997). Numerous algicidal bacteria have been identified in the ocean, and their influence on algal bloom dynamics has been demonstrated (Mayali and Azam, 2004). Although they have not yet been associated with real economic losses in cultures, the experience in production of other marine species suggests that diseases will likely appear in parallel with the expansion of the industry. Viruses are extremely abundant in seawater and are believed to be significant pathogens to photosynthetic protists. They are known to affect the regulation of eukaryotic phytoplankton population densities. Since the discovery of the very high abundance of viruses in the marine environment, researchers have highlighted their possible ecological significance. To date, more than 40 viruses infecting marine microalgae have been isolated and characterised to different extents (Nagasaki, 2008). Several studies have focused on the relationship between eukaryotic microalgae and their viruses (for review see Nagasaki, 2008). Without going into great detail, it is interesting to note that most algae can use various strategies of resistance to their viruses, but the mechanisms involved are not yet clearly understood (Morin, 2008, Thomas et al., 2011). The next chapter of this volume, Genomics of Algal Host-Virus Interactions', reviews algal host-virus interactions. Finally, it 
will be interesting to compare the emergence of pathogens such as plant viruses during this new agricultural revolution and increase in demand for algal culture by industry. Microalgal cultivation remains a niche market in almost all countries, but the increasing interest in sustainable biofuel sources has triggered a high investment in culture facilities all over the world. Consequently, intensive algal aquaculture using open pond systems for the mass culture of microalgae might favour disease outbreaks. Gachon et al. (2010) suggest that development towards intensive macroalgal production correlates with more damaging disease outbreaks. The best example is the case of edible red macroalgae Porphyra sp., which represent a very valuable industry in Asia. The market is estimated to be worth about $\$ 1.5$ billion worldwide, and has reported losses of about $10 \%$ of annual production due to oomycete pathogens, although these outbreaks can even lead to losses of 25 to $40 \%$ in some cases. To overcome this problem, sea farmers can use chemical treatments, but their use in large doses could have a real impact on ecosystems, as well as on production costs. A better understanding of the relationships between pathogens and microalgae would be useful to identify causes and possible solutions to overcome disease epidemics. Prophylactic and microbial flora management of cultures will probably be a key to the durability of production in the coming years. Varietal selection of microalgal strains for resistance to a large range of pathogens is one strategy that could increase the resistance of microalgae cultures. In any case, in the context of intensive microalgal production, we must anticipate future epidemics that will affect algal culture yields.

\section{Conclusion}

Due to the huge amount of diversity among microalgae, their applications have a very bright future. As seen in this chapter, the uses of microalgae are numerous and there is work for many research teams in many fields of specialisation.

Genomics and post-genomics have led to new areas of research and development and to the modernisation of our view of biology. The increase in sequencing capacities will soon face a data tsunami, a fantastic amount of data that will soon be generated by fast, low-cost sequencing methods. However, storage, calculation power, annotations and access to this information now pose a limit to its optimal exploration. Data mining and conversion of data into biological knowledge will be an important challenge in coming years. The confirmation of all the in silico analyses and discoveries will require a return to experimental testing, and the association of molecular data with biological functions will become vital work in the future (Lopez et al., 2011).

The culture of microalgae for biomass production dates back to the 1940s, when it started in the USA before spreading to Europe, Japan and Israel (Grobbelaar, 2010). Since then, work has continued all over the world at different speeds, with irregular publication rates. Some of the early work still forms the basis for the today's revival of the microalgal trend (Sheehan et al., 1998). The dramatic increase in the world population, concerns about the ecological equilibrium, pollution, the world energy demand and failing supplies of oil and coal have all led to a more bio'-orientated attitude, meaning a general increase in the attention paid to renewable' resources. From a global perspective, in the context of a demographic crisis, the major issues in the coming years will be to provide everyone with access to water, food, education and healthcare. In a world of limited resources (energy, clean water, arable land) and increasing anthropogenic pressure on the environment, the development of biotechnological processes to provide renewable energy, new molecules and molecular farming and cleaner industrial processes is one of the key challenges. Marine microalgae possess assets that make them suitable for some of these applications. While land plants are the subject of numerous programs aiming to use vegetal organisms for the so-called green chemistry', the algae, particularly microalgae, are expected to participate in this race in a 
complementary way. Although far less studied than their terrestrial counterparts, microalgae offer an, as yet, untapped diversity and manipulability that explain the enthusiasm and investment from around the world. Phytoplankton research is being revisited and enriched by modern techniques like molecular biology and biocomputing, and the omics' technologies offer new insights into their biology. The young generation of students will have the chance, at the strictly scientific level, to be present when the majority of the genomes are still to be sequenced, the transcriptome is unknown and even the reproductive strategies or size of the genomes are undefined. The earth still hides a tremendous amount of original biology, including much that concerns microalgae. Their discovery, study, analysis and use will serve applications in all imaginable fields.

\section{References}

Abe J., Hiwatashi Y., Ito M., Hasebe M. and Sekimoto H. (2008). Expression of Exogenous Genes Under the Control of Endogenous HSP70 and CAB Promoters in the Closterium peracerosum-strigosum-littorale complex. Plant and Cell Physiology 49, 625-632.

Abe J., Hori S., Tsuchikane Y., Kitao N., Kato M. and Sekimoto H. (2011). Stable Nuclear Transformation of the Closterium peracerosum-strigosum-littorale Complex. Plant and Cell Physiology 52, 1676-1685.

AbuGhazaleh A. A., Potu R. B. and Ibrahim S. (2009). Short communication: The effect of substituting fish oil in dairy cow diets with docosahexaenoic acid-micro algae on milk composition and fatty acids profile. Journal of Dairy Science 92, 6156-6159.

Anila N., Chandrashekar A., Ravishankar G. A. and Sarada R. (2011). Establishment of Agrobacterium tumefaciens-mediated genetic transformation in Dunaliella bardawil. European Journal of Phycology 46, 36-44.

Apt K. E., Kroth-Pancic P. G. and Grossman A. R. (1996). Stable nuclear transformation of the diatom Phaeodactylum tricornutum. Molecular and General Genetics 252, 572579.

Auchincloss A. H., Loroch A. I. and Rochaix J. D. (1999). The argininosuccinate lyase gene of Chlamydomonas reinhardtii: cloning of the cDNA and its characterization as a selectable shuttle marker. Molecular and General Genetics 261, 21-30.

Baba M., loki M., Nakajima N., Shiraiwa Y. and Watanabe M. M. (2011). Transcriptome analysis of an oil-rich race A strain of Botryococcus braunii (BOT-88-2) by de novo assembly of pyrosequencing cDNA reads. Bioresource Technology 109, 282-286.

Baiet B., Burel C., Saint-Jean B., Louvet R., Menu-Bouaouiche L., Kiefer-Meyer M. C., Mathieu-Rivet E., Lefebvre T., Castel H., Carlier A., Cadoret J. P., Lerouge P. and Bardor M. (2011). N-Glycans of Phaeodactylum tricornutum Diatom and Functional Characterization of Its N-Acetylglucosaminyltransferase I Enzyme. The Journal of Biological Chemistry 286, 6152-6164.

Bakker, H., Bardor M., Molthoff J. W., Gomord V., Elbers I., Stevens L. H., Jordi W., Lommen A., Faye L., Lerouge P., and Bosch D. (2001). Galactose-extended glycans of antibodies produced by transgenic plants. Proceedings of the National Academy of Sciences of the United States of America 98, 2899-2904.

Barbier, G., Oesterhelt C., M. Larson D., Halgren R. G., Wilkerson C., Garavito R. M., Benning C., and Weber A. P. M. (2005). Comparative genomics of two closely related unicellular thermo-acidophilic red algae, Galdieria sulphuraria and Cyanidioschyzon merolae, reveals the molecular basis of the metabolic flexibility of Galdieria sulphuraria and significant differences in carbohydrate metabolism of both algae. Plant Physiology 137, 460-474.

Barnes D., Franklin S., Schultz J., Henry R., Brown E., Coragliotti A. and Mayfield S. P. (2005). Contribution of 5'- and $3^{\prime}$-untranslated regions of plastid mRNAs to the 
expression of Chlamydomonas reinhardtii chloroplast genes. Molecular Genetics and Genomics 274, 625-636.

Becker W. (2007). Microalgae in Human and Animal Nutrition. In Handbook of Microalgal Culture. Biotechnology and Apllied Phycology" (A. Richmond, eds.), pp. 312-351. Oxford: Blackwell Science.

Berthold P., Schmitt R. and Mages W. (2002). An engineered Streptomyces hygroscopicus aph 7" gene mediates dominant resistance against hygromycin B in Chlamydomonas reinhardtii. Protist 153, 401-412.

Bhadury P. and Wright P. C. (2004). Exploitation of marine algae: biogenic compounds for potential antifouling applications. Planta 219, 561-578.

Blanc G., Duncan G., Agarkova I., Borodovsky M., Gurnon J., Kuo A., Lindquist E., Lucas S., Pangilinan J., Polle J., Salamov A., Terry A., Yamada T., Dunigan D. D., Grigoriev I. V., Claverie J. M. and Van Etten J. L. (2010). The Chlorella variabilis NC64A Genome Reveals Adaptation to Photosymbiosis, Coevolution with Viruses, and Cryptic Sex. The Plant Cell 22, 2943-2955.

Blankenship J. E. and Kindle K. L. (1992). Expression of Chimeric Genes by the LightRegulated Cabii-1 Promoter in Chlamydomonas-Reinhardtii - a Cabii-1/Nit1 Gene Functions as a Dominant Selectable Marker in a Nit1- Nit2- Strain. Molecular and Cellular Biology 12, 5268-5279.

Bock R. (2007). Plastid biotechnology: prospects for herbicide and insect resistance, metabolic engineering and molecular farming. Current Opinion in Biotechnology 18, 100-106.

Bonente G., Formighieri C., Morosinotto T. and Bassi R. (2011). Domestication of wild unicellular algae for growth in photobioreactors. FEBS Journal 278, 64-65.

Bowler C., Allen A. E., Badger J. H., Grimwood J., Jabbari K., Kuo A., Maheswari U., Martens C., Maumus F., Otillar R. P., Rayko E., Salamov A., Vandepoele K., Beszteri B., Gruber A., Heijde M., Katinka M., Mock T., Valentin K., Verret F., Berges J. A., Brownlee C., Cadoret J. P., Chiovitti A., Choi C. J., Coesel S., De Martino A., Detter J. C., Durkin C., Falciatore A., Fournet J., Haruta M., Huysman M. J., Jenkins B. D., Jiroutova K., Jorgensen R. E., Joubert Y., Kaplan A., Kroger N., Kroth P. G., La Roche J., Lindquist E., Lommer M., Martin-Jezequel V., Lopez P. J., Lucas S., Mangogna M., McGinnis K., Medlin L. K., Montsant A., Oudot-Le Secq M. P., Napoli C., Obornik M., Parker M. S., Petit J. L., Porcel B. M., Poulsen N., Robison M., Rychlewski L., Rynearson T. A., Schmutz J., Shapiro H., Siaut M., Stanley M., Sussman M. R., Taylor A. R., Vardi A., von Dassow P., Vyverman W., Willis A., Wyrwicz L. S., Rokhsar D. S., Weissenbach J., Armbrust E. V., Green B. R., Van de Peer Y. and Grigoriev I. V. (2008). The Phaeodactylum genome reveals the evolutionary history of diatom genomes. Nature 456, 239-44.

Bozarth A., Maier U. G. and Zauner S. (2009). Diatoms in biotechnology: modern tools and applications. Applied Microbiology and Biotechnology 82, 195-201.

Brown L. E., Sprecher, S. L. and Keller, L. R. (1991). Introduction of exogenous DNA into Chlamydomonas reinhardtii by electroporation. Molecular and Cellular Biology 11, (4) 2328-2332.

Cadoret J.-P., Bardor M., Lerouge P., Cabigliera M., Henriquez V. and Carlier A. (2008). Les microalgues : Usines cellulaires productrices de molécules commerciales recombinantes. Medecine Science 24, 375-382.

Cadoret J. P., Carlier A., Burel C., Maury F., Bardor M. and Lerouge P. (2009). Production of glysosylated proteins in microalgae. PCT/EP/2009/051672.

Camacho F. G., Rodríguez J. G., Mirón A. S., García M. C. C., Belarbi E. H., Chisti Y. and Grima E. M. (2006). Biotechnological significance of toxic marine dinoflagellates. Biotechnology Advances 25, 176-194.

Cerutti H., Johnson A. M., Gillham N. W. and Boynton J. E. (1997). A eubacterial gene conferring spectinomycin resistance on Chlamydomonas reinhardtii: Integration into the nuclear genome and gene expression. Genetics 145, 97-110. 
Cha T. S., Chen C. F., Yee W., Aziz A. and Loh S. H. (2011a). Cinnamic acid, coumarin and vanillin: Alternative phenolic compounds for efficient Agrobacterium-mediated transformation of the unicellular green alga, Nannochloropsis $\mathrm{sp}$. Journal of Microbiological Methods 84, 430-434.

Cha T. S., Yee W. and Aziz A. (2011b). Assessment of factors affecting Agrobacteriummediated genetic transformation of the unicellular green alga, Chlorella vulgaris. World Journal of Microbiology \& Biotechnology doi:10.1007/s11274-011-0991-0.

Chaturvedi R. and Fujita Y. (2006). Isolation of enhanced eicosapentaenoic acid producing mutants of Nannochloropsis oculata ST-6 using ethyl methane sulfonate induced mutagenesis techniques and their characterization at mRNA transcript level. Phycological Research 54, 208-219.

Chen Y., Wang Y. Q., Sun Y. R., Zhang L. M. and Li W. B. (2001). Highly efficient expression of rabbit neutrophil peptide-1 gene in Chlorella ellipsoidea cells. Current Genetics 39, 365-370.

Chen H. L., Li S. S., Huang R. and Tsai H. J. (2008). Conditional production of a functional fish growth hormone in the transgenic line of Nannochloropsis oculata (Eustigmatophyceae). Journal of Phycology 44, 768-776.

Chepurnov V. A., Chaerle P., Roef L., Meirhaeghe A. and Vanhoutte K. (2011). Classical Breeding in Diatoms: Scientific Background and Practical Perspectives. In The Diatom World" (J. Seckbach and P. Kociolek, eds.), pp. 167-194. Springer Netherlands.

Chow K. C. and Tung W. L. (1997). Electrotransformation of Chlorella vulgaris. Plant Physiology 114, 1610-1610.

Chow K. C. and Tung W. L. (1999). Electrotransformation of Chlorella vulgaris. Plant Cell Reports 18, 778-780.

Coesel S., Mangogna M., Ishikawa T., Heijde M., Rogato A., Finazzi G., Todo T., Bowler C. and Falciatore A. (2009). Diatom PtCPF1 is a new cryptochrome/photolyase family member with DNA repair and transcription regulation activity. EMBO Reports 10, 655661.

Conley A. J., Mohib K., Jevnikar A. M. and Brandle J. E. (2009). Plant recombinant erythropoietin attenuates inflammatory kidney cell injury. Plant Biotechnology Journal 7, 183-99.

Cordero B. F., Couso I., Leon R., Rodriguez H. and Angeles Vargas M. (2011). Enhancement of carotenoids biosynthesis in Chlamydomonas reinhardtii by nuclear transformation using a phytoene synthase gene isolated from Chlorella zofingiensis. Applied Microbiology and Biotechnology 91, 341-351.

Croft M. T., Moulin M., Webb M. E. and Smith A. G. (2007). Thiamine biosynthesis in algae is regulated by riboswitches. Proceedings of the National Academy of Sciences of the United States of America 104, 20770-20775.

Cui Y. L., Wang J. F., Jiang P., Bian S. G. and Qin S. (2010). Transformation of Platymonas (Tetraselmis) subcordiformis (Prasinophyceae, Chlorophyta) by agitation with glass beads. World Journal of Microbiology \& Biotechnology 26, 1653-1657.

Cui H., Wang Y. and Qin S. (2011). Molecular Evolution of Lycopene Cyclases Involved in the Formation of Carotenoids in Eukaryotic Algae. Plant Molecular Biology Reporter 29, 1013-1020.

Das B. K., Roy A., Koschorreck M., Mandal S. M., Wendt-Potthoff K. and Bhattacharya J. (2009). Occurrence and role of algae and fungi in acid mine drainage environment with special reference to metals and sulfate immobilization. Water Research 43, 883894.

Dauvillee D., Delhaye S., Gruyer S., Slomianny C., Moretz S. E., d'Hulst C., Long C. A., Ball S. G. and Tomavo S. (2010). Engineering the Chloroplast Targeted Malarial Vaccine Antigens in Chlamydomonas Starch Granules. PLoS ONE 5, (12): e15424. doi:10.1371/journal.pone. 
Dawson H. N., Burlingame R. and Cannons A. C. (1997). Stable transformation of Chlorella: Rescue of nitrate reductase-deficient mutants with the nitrate reductase gene. Current Microbiology 35, 356-362.

Debuchy R., Purton, S. and Rochaix, J-D. (1989). The arginosuccinate lyase gene of Chlamydomonas reinhardtii: an important tool for nuclear transformation and for correlating the genetic and molecular maps of the ARG7 locus. EMBO Journal 8 , (10) 2803-2809.

Desmond E. and Gribaldo S. (2009). Phylogenomics of Sterol Synthesis: Insights into the Origin, Evolution, and Diversity of a Key Eukaryotic Feature. Genome Biology and Evolution 1, 364-381.

Dittami S. M., Riisberg I., John U., Orr R. J. S., Jakobsen K. S. and Edvardsen B. (2011). Analysis of Expressed Sequence Tags from the Marine Microalga Pseudochattonella farcimen (Dictyochophyceae). Protist 163, 143-161.

Doetsch N. A., Favreau M. R., Kuscuoglu N., Thompson M. D. and Hallick R. B. (2001). Chloroplast transformation in Euglena gracilis: splicing of a group III twintron transcribed from a transgenic psbK operon. Current Genetics 39, 49-60.

Doran P. M. (2006). Foreign protein degradation and instability in plants and plant tissue cultures. Trends in Biotechnology 24, 426-432.

Dove A. (2002). Uncorking the biomanufacturing bottleneck. Nature Biotechnology 20, 777 779.

Dreesen I. A. J., Charpin-El Hamri G. and Fussenegger M. (2010). Heat-stable oral algabased vaccine protects mice from Staphylococcus aureus infection. Journal of Biotechnology 145, 273-280.

Dunahay T. G., Jarvis E. E. and Roessler P. G. (1995). Genetic transformation of the diatoms Cyclotella cryptica and Navicula saprophila. Journal of Phycology 31, 10041012.

Dunahay T., Jarvis E., Dais S. and Roessler P. (1996). Manipulation of microalgal lipid production using genetic engineering. Applied Biochemistry and Biotechnology 57, (8) 223-231.

Ebenezer V., Medlin L. and Ki J.-S. (2011). Molecular Detection, Quantification, and Diversity Evaluation of Microalgae. Marine Biotechnology 14, (2) 129-142.

Eichler-Stahlberg A., Weisheit W., Ruecker O. and Heitzer M. (2009). Strategies to facilitate transgene expression in Chlamydomonas reinhardtii. Planta 229, 873-883.

Eom, H., Lee C.G. and Jin. E. (2005). Gene expression profile analysis in astaxanthininduced Haematococcus pluvialis using a cDNA microarray. Planta 223, 1231-1242.

Falciatore A., Casotti R., Leblanc C., Abrescia C. and Bowler C. (1999). Transformation of Nonselectable Reporter Genes in Marine Diatoms. Marine Biotechnology 1, 239-251.

Fan J., Andre C. and Xu C. (2011). A chloroplast pathway for the de novo biosynthesis of triacylglycerol in Chlamydomonas reinhardtii. FEBS Letters 585, (12) 1985-1991.

Feng S. Y., Xue L. X., Liu H. T. and Lu P. J. (2009). Improvement of efficiency of genetic transformation for Dunaliella salina by glass beads method. Molecular Biology Reports 36, 1433-1439.

Finazzi, G., Moreau H., and Bowler C. (2010). Genomic insights into photosynthesis in eukaryotic phytoplankton. Trends in Plant Science 15, 565-572.

Fischer H., Robl I., Sumper M. and Kroger N. (1999). Targeting and covalent modification of cell wall and membrane proteins heterologously expressed in the diatom Cylindrotheca fusiformis (Bacillariophyceae). Journal of Phycology 35, 113-120.

Fischer and Rochaix (2001). The flanking regions of $P s a D$ drive efficient gene expression in the nucleus of the green alga Chlamydomonas reinhardtii. Molecular Genetics and Genomics 265, 888-894.

Franklin S., Ngo B., Efuet E. and Mayfield S. (2002). Development of a GFP reporter gene for Chlamydomonas reinhardtii chloroplast. Plant Journal 30, 733-744.

Frommolt R., Werner S., Paulsen H., Goss R., Wilhelm C., Zauner S., Maier U. G., Grossman A. R., Bhattacharya D. and Lohr M. (2008). Ancient Recruitment by 
Chromists of Green Algal Genes Encoding Enzymes for Carotenoid Biosynthesis. Molecular Biology and Evolution 25, 2653-2667.

Fuhrmann M., Oertel W. and Hegemann P. (1999). A synthetic gene coding for the green fluorescent protein (GFP) is a versatile reporter in Chlamydomonas reinhardtii. Plant Journal 19, 353-361.

Fukami K., Nishijima T. and Ishida Y. (1997). Stimulative and inhibitory effects of bacteria on the growth of microalgae. Hydrobiologia 358, 185-191.

Gachon C. M. M., Sime-Ngando T., Strittmatter M., Chambouvet A. and Kim G. H. (2010). Algal diseases: spotlight on a black box. Trends in Plant Science 15, 633-640.

Gasdaska, J. R., Spencer D., and Dickey L. (2003). Advantages of therapeutic protein production in the aquatic plant Lemna. BioProcessing Journal 2, (2) 49-56.

Geng D. G., Wang Y. Q., Wang P., Li W. B. and Sun Y. R. (2003). Stable expression of hepatitis B surface antigen gene in Dunaliella salina (Chlorophyta). Journal of Applied Phycology 15, 451-456.

Gobler C. J., Berry D. L., Dyhrman S. T., Wilhelm S. W., Salamov A., Lobanov A. V., Zhang Y., Collier J. L., Wurch L. L., Kustka A. B., Dill B. D., Shah M., VerBerkmoes N. C., Kuo A., Terry A., Pangilinan J., Lindquist E. A., Lucas S., Paulsen I. T., HattenrathLehmann T. K., Talmage S. C., Walker E. A., Koch F., Burson A. M., Marcoval M. A., Tang Y. Z., LeCleir G. R., Coyne K. J., Berg G. M., Bertrand E. M., Saito M. A., Gladyshev V. N. and Grigoriev I. V. (2011). Niche of harmful alga Aureococcus anophagefferens revealed through ecogenomics. Proceedings of the National Academy of Sciences of the United States of America 108, 4352-4357.

Gomord W., Sourrouille C., Fitchette A. C., Bardor M., Pagny S., Lerouge P. and Faye L. (2004). Production and glycosylation of plant-made pharmaceuticals: the antibodies as a challenge. Plant Biotechnology Journal 2, 83-100.

Gould, S. B., Waller R. F., and McFadden G. I. (2008). Plastid Evolution. Annual Review of Plant Biology 59, 491-517

Gourdon D., Lin Q., Oroudjev E., Hansma H., Golan Y., Arad S. and Israelachvili J. (2008). Adhesion and stable low friction provided by a subnanometer-thick monolayer of a natural polysaccharide. Langmuir 24, 1534-1540.

Gouveia L., Coutinho C., Mendonca E., Batista A. P., Sousa I., Bandarra N. M. and Raymundo A. (2008). Functional biscuits with PUFA-omega 3 from Isochrysis galbana. Journal of the Science of Food and Agriculture 88, 891-896.

Grobbelaar J. (2010). Microalgal biomass production: challenges and realities. Photosynthesis Research 106, 135-144.

Guarnieri M. T., Nag A., Smolinski S. L., Darzins A., Seibert M. and Pienkos P. T. (2011). Examination of Triacylglycerol Biosynthetic Pathways via De Novo Transcriptomic and Proteomic Analyses in an Unsequenced Microalga. PLoS ONE 6, e25851. doi:10.1371/journal.pone.0025851.

Guschina I. A. and Harwood J. L. (2006). Lipids and lipid metabolism in eukaryotic algae. Progress in Lipid Research 45, 160-186.

Habib M. A. B., Huntington T., Hasan M. R. (2008). A review on culture, production and use of Spirulina as food for humans and feeds for domestic animals and fish. FAO Fisheries and Aquaculture Circular No. 1034.

Hall L. M., Taylor K. B. and Jones D. D. (1993). Expression of a foreign gene in Chlamydomonas reinhardtii. Gene 124, 75-81.

Hallmann A., Amon P., Godl K., Heitzer M. and Sumper M. (2007). Algal Transgenics and Biotechnology. Transgenic Plant Journal 1, 81-98.

Harada H. and Matsuda Y. (2005). Promoter analysis of two CO2-inducible carbonic anhydrases in the marine diatom Phaeodactylum tricornutum. Plant and Cell Physiology 46, 88-89.

Hawkins R. L. and Nakamura M. (1999). Expression of human growth hormone by the eukaryotic alga, Chlorella. Current Microbiology 38, 335-341.

He D. M., Qian K. X., Shen G. F., Zhang Z. F., Li Y. N., Su Z. L. and Shao H. B. (2007). Recombination and expression of classical swine fever virus (CSFV) structural protein 
E2 gene in Chlamydomonas reinhardtii chroloplasts. Colloids and Surfaces $B$ Biointerfaces 55, 26-30.

Hempel F., Bozarth A. S., Lindenkamp N., Klingl A., Zauner S., Linne U., Steinbuchel A. and Maier U. G. (2011a). Microalgae as bioreactors for bioplastic production. Microbial Cell Factories doi:10.1186/1475-2859-10-81.

Hempel F., Lau J., Klingl A. and Maier U. G. (2011b). Algae as Protein Factories: Expression of a Human Antibody and the Respective Antigen in the Diatom Phaeodactylum tricornutum. PLoS ONE 6, (12) e28424. doi:10.1371/journal.pone.0028424.

Hermsmeier D., Schulz R. and Senger H. (1994). Formation of light-harvesting complexes of photosystem II in Scenedesmus. 1. Correlations between amounts of photosynthetic pigments, Lhc messenger RNAs and LHC apoproteins during constitutional dark- and light-dependent Lhc-gene expression. Planta 193, 398-405.

Hirakawa Y., Kofuji R. and Ishida K. (2008). Transient transformation of a chlorarachniophyte alga, Lotharella amoebiformis (chlorarachniophyceae), with uidA and egfp reporter genes. Journal of Phycology 44, 814-820.

Hu Q., Sommerfeld M., Jarvis E., Ghirardi M., Posewitz M., Seibert M. and Darzins A. (2008). Microalgal triacylglycerols as feedstocks for biofuel production: perspectives and advances. Plant Journal 54, 621-639.

Huheihel M., Ishanu V., Tal J. and Arad S. (2002). Activity of Porphyridium sp polysaccharide against herpes simplex viruses in vitro and in vivo. Journal of Biochemical and Biophysical Methods 50, 189-200.

Iomini C., Till J. E. and Dutcher S. K. (2009). Gilia: Model Organisms and Intraflagellar Transport". Methods in Cell Biology 93, pp. 121. Academic Press.

Janssen M., Tramper J., Mur L. R. and Wijffels R. H. (2003). Enclosed outdoor photobioreactors: Light regime, photosynthetic efficiency, scale-up, and future prospects. Biotechnology and Bioengineering 81, 193-210.

Jarvis E. E. and Brown L. M. (1991). Transient expression of firefly luciferase in protoplasts of the green alga Chlorella ellipsoidea. Current Genetics 19, 317-321.

Karsenti E., Acinas S. G., Bork P., Bowler C., De Vargas C., Raes J., Sullivan M., Arendt D., Benzoni F., Claverie J. M., Follows M., Gorsky G., Hingamp P., ludicone D., Jaillon O., Kandels-Lewis S., Krzic U., Not F., Ogata H., Pesant S., Reynaud E. G., Sardet C., Sieracki M. E., Speich S., Velayoudon D., Weissenbach J. and Wincker P. (2011). A Holistic Approach to Marine Eco-Systems Biology. PLoS Biology 9, e1001177. doi:10.1371/journal.pbio.1001177.

Kathiresan S., Chandrashekar A., Ravishankar G. A. and Sarada R. (2009). AgrobacteriumMediated Transformation in the Green Alga Haematococcus Pluvialis (Chlorophyceae, Volvocales). Journal of Phycology 45, 642-649.

Kato T., Kolenic N. and Pardini R. S. (2007). Docosahexaenoic acid (DHA), a primary tumor suppressive omega-3 fatty acid, inhibits growth of colorectal cancer independent of p53 mutational status. Nutrition and Cancer 58, 178-187.

Katz A., Waridel P., Shevchenko A. and Pick U. (2007). Salt-induced Changes in the Plasma Membrane Proteome of the Halotolerant Alga Dunaliella salina as Revealed by Blue Native Gel Electrophoresis and Nano-LC-MS/MS Analysis. Molecular \& Cellular Proteomics 6, 1459-1472.

Khozin-Goldberg I. and Cohen Z. (2011). Unraveling algal lipid metabolism: Recent advances in gene identification. Biochimie 93, 91-100.

Kilian O., Benemann C., Niyogi K. and Vick B. (2011). High-efficiency homologous recombination in the oil-producing alga Nannochloropsis sp. Proceedings of the National Academy of Sciences of the United States of America 108, 21265-21269.

Kim D. H., Kim Y. T., Cho J. J., Bae J. H., Hur S. B., Hwang I. and Choi T. J. (2002). Stable integration and functional expression of flounder growth hormone gene in transformed microalga, Chlorella ellipsoidea. Marine Biotechnology 4, 63-73.

Kim, J., Lee W., Kim B., and Lee C. (2006). Proteomic analysis of protein expression patterns associated with astaxanthin accumulation by green alga Haematococcus 
pluvialis (Chlorophyceae) under high light stress. Journal of Microbiology and Biotechnology 16, 1222-1228.

Ko K., Tekoah Y., Rudd P. M., Harvey D. J., Dwek R. A., Spitsin S., Hanlon C. A., Rupprecht C., Dietzschold B., Golovkin M. and Koprowski H. (2003). Function and glycosylation of plant-derived antiviral monoclonal antibody. Proceedings of the National Academy of Sciences of the United States of America 100, 8013-8018.

Kovar J. L., Zhang J., Funke R. P. and Weeks D. P. (2002). Molecular analysis of the acetolactate synthase gene of Chlamydomonas reinhardtii and development of a genetically engineered gene as a dominant selectable marker for genetic transformation. Plant Journal 29, 109-117.

Kozminski K. G., Diener D. R. and Rosenbaum J. L. (1993). High-Level Expression of Nonacetylatable Alpha-Tubulin in Chlamydomonas-Reinhardtii. Cell Motility and the Cytoskeleton 25, 158-170.

Kumar S., Misquitta R., Reddy V., Rao B. and Rajam M. (2004). Genetic transformation of the green alga - Chlamydomonas reinhardtii by Agrobacterium tumefaciens. Plant Science 166, 731-738.

Lapidot M., Raveh D., Sivan A., Arad S. and Sapira M. (2002). Stable chloroplaste transformation of the unicellular red alga Porphyridium species. Plant Physiology 129, 7-12.

Lerche K. and Hallmann A. (2009). Stable nuclear transformation of Gonium pectorale. BMC Biotechnology 9, doi:10.1186/1472-6750-9-64.

Levy-Ontman O., Arad S. M., Harvey D. J., Parsons T. B., Fairbanks A. and Tekoah Y. (2011). Unique $\mathrm{N}$-glycan moieties of the 66-kDa cell wall glycoprotein from the red microalga Porphyridium sp. The Journal of Biological Chemistry 286, 21340-21352.

Li H., Xue L., Yana H., Wang L., Liu L., Lu Y. and Xie H. (2007). The nitrate reductase geneswitch: A system for regulated expression in transformed cells of Dunaliella salina. Gene 403, 132-142.

Li J., Xue L. X., Yan H. X., Liu H. T. and Liang J. Y. (2008a). Inducible EGFP expression under the control of the nitrate reductase gene promoter in transgenic Dunaliella salina. Journal of Applied Phycology 20, 137-145.

Li S. S. and Tsai H. J. (2008b). Transgenic microalgae as a non-antibiotic bactericide producer to defend against bacterial pathogen infection in the fish digestive tract. Fish \& Shellfish Immunology 26, 316-325.

Li Y., Han D., Hu G., Sommerfeld M. and Hu Q. (2010a). Inhibition of Starch Synthesis Results in Overproduction of Lipids in Chlamydomonas reinhardtii. Biotechnology and Bioengineering 107, 258-268.

Li Y. T., Han D. X., Hu G. R., Dauvillee D., Sommerfeld M., Ball S. and Hua Q. (2010b). Chlamydomonas starchless mutant defective in ADP-glucose pyrophosphorylase hyper-accumulates triacylglycerol. Metabolic Engineering 12, 387-391.

Liska A. J. (2004). Enhanced Photosynthesis and Redox Energy Production Contribute to Salinity Tolerance in Dunaliella as Revealed by Homology-Based Proteomics. Plant Physiology 136, 2806-2817.

Llamas A., Igeno M. I., Galvan A. and Fernandez E. (2002). Nitrate signalling on the nitrate reductase gene promoter depends directly on the activity of the nitrate transport systems in Chlamydomonas. Plant Journal 30, 261-271.

Lohr M., Schwender J. and Polle J. E. W. (2012). Isoprenoid biosynthesis in eukaryotic phototrophs: A spotlight on algae. Plant Science 185, 9-22.

Lopez D., Casero D., Cokus S., Merchant S. and Pellegrini M. (2011). Algal Functional Annotation Tool: a web-based analysis suite to functionally interpret large gene lists using integrated annotation and expression data. BMC Bioinformatics 12, doi:10.1186/1471-2105-12-282.

Lorenz R. T. and Cysewski G. R. (2000). Commercial potential for Haematococcus microalgae as a natural source of astaxanthin. Trends in Biotechnology 18, 160-167.

Lumbreras V. and Purton S. (1998). Recent advances in Chlamydomonas transgenics. Protist 149, 23-27. 
Maheswari U., Mock T., Armbrust E. V. and Bowler C. (2009). Update of the Diatom EST Database: a new tool for digital transcriptomics. Nucleic Acids Research 37, 10011005

Manuell A. L., Beligni M. V., Elder J. H., Siefker D. T., Tran M., Weber A., McDonald T. L. and Mayfield S. P. (2007). Robust expression of a bioactive mammalian protein in Chlamydomonas chloroplast. Plant Biotechnology Journal 5, 402-412.

Marin-Navarro J., Manuell A. L., Wu J. and Mayfield S. P. (2007). Chloroplast translation regulation. Photosynthesis Research 94, 359-374.

Matsui M. S., Muizzuddin N., Arad S. and Marenus K. (2003). Sulfated polysaccharides from red microalgae have antiinflammatory properties in vitro and in vivo. Applied Biochemistry and Biotechnology 104, 13-22.

Matsuo T. and Ishiura M. (2011). Chlamydomonas reinhardtii as a new model system for studying the molecular basis of the circadian clock. FEBS Letters 585, 1495-1502.

Mayali X. and Azam F. (2004). Algicidal bacteria in the sea and their impact on algal blooms. The Journal of Eukaryotic Microbiology 51, 139-144.

Mayfield S. P., Franklin S. E. and Lerner R. A. (2003). Expression and assembly of a fully active antibody in algae. Proceedings of the National Academy of Sciences of the United States of America 100, 438-442.

Mayfield S. and Schultz J. (2004). Development of a luciferase reporter gene, luxCt, for Chlamydomonas reinhardtii chloroplast. Plant Journal 37, 449-458.

Mayfield S. P. and Franklin S. E. (2005). Expression of human antibodies in eukaryotic micro-algae. Vaccine 23, 1828-1832.

Meireles L., Guedes A. C. and Malcata F. X. (2003). Increase of the yields of eicosapentaenoic and docosahexaenoic acids by the microalga Pavlova lutheri following random mutagenesis. Biotechnology and Bioengineering 81, 50-55.

Mendoza H., de la Jara A., Freijanes K., Carmona L., Ramos A.A., de Sousa Duarte V. and Valera J. C. S. (2008). Characterization od Dunaliella salina strains by flow cytometry: a new approach to select carotenoid hyperproducing strains. Electron Journal of Biotechnology 11, 1-13.

Merchant S. S., Prochnik S. E., Vallon O., Harris E. H., Karpowicz S. J., Witman G. B., Terry A., Salamov A., Fritz-Laylin L. K., Marechal-Drouard L., Marshall W. F., Qu L. H., Nelson D. R., Sanderfoot A. A., Spalding M. H., Kapitonov V. V., Ren Q., Ferris P., Lindquist E., Shapiro H., Lucas S. M., Grimwood J., Schmutz J., Cardol P., Cerutti H., Chanfreau G., Chen C. L., Cognat V., Croft M. T., Dent R., Dutcher S., Fernandez E., Fukuzawa H., Gonzalez-Ballester D., Gonzalez-Halphen D., Hallmann A., Hanikenne M., Hippler M., Inwood W., Jabbari K., Kalanon M., Kuras R., Lefebvre P. A., Lemaire S. D., Lobanov A. V., Lohr M., Manuell A., Meier I., Mets L., Mittag M., Mittelmeier T., Moroney J. V., Moseley J., Napoli C., Nedelcu A. M., Niyogi K., Novoselov S. V., Paulsen I. T., Pazour G., Purton S., Ral J. P., Riano-Pachon D. M., Riekhof W., Rymarquis L., Schroda M., Stern D., Umen J., Willows R., Wilson N., Zimmer S. L., Allmer J., Balk J., Bisova K., Chen C. J., Elias M., Gendler K., Hauser C., Lamb M. R., Ledford H., Long J. C., Minagawa J., Page M. D., Pan J., Pootakham W., Roje S., Rose A., Stahlberg E., Terauchi A. M., Yang P., Ball S., Bowler C., Dieckmann C. L., Gladyshev V. N., Green P., Jorgensen R., Mayfield S., Mueller-Roeber B., Rajamani S., Sayre R. T. and Brokstein P. (2007). The Chlamydomonas genome reveals the evolution of key animal and plant functions. Science 318, 245-50.

Merchant S. S., Kropat J., Liu B., Shaw J. and Warakanont J. (2011). TAG, You're it! Chlamydomonas as a reference organism for understanding algal triacylglycerol accumulation. Current Opinion in Biotechnology doi:10.1016/j.copbio.2011.12.001.

Miller R., Wu G. X., Deshpande R. R., Vieler A., Gartner K., Li X. B., Moellering E. R., Zauner S., Cornish A. J., Liu B. S., Bullard B., Sears B. B., Kuo M. H., Hegg E. L., ShacharHill Y., Shiu S. H. and Benning C. (2010). Changes in Transcript Abundance in Chlamydomonas reinhardtii following Nitrogen Deprivation Predict Diversion of Metabolism. Plant Physiology 154, 1737-1752. 
Minoda A., Sakagami R., Yagisawa F., Kuroiwa T. and Tanaka K. (2004). Improvement of culture conditions and evidence for nuclear transformation by homologous recombination in a red alga, cyanidioschyzon merolae 10D. Plant and Cell Physiology 45, 667-671.

Mitra A., Higgins D. W. and Rohe N. J. (1994). A Chlorella Virus Gene Promoter Functions as a Strong Promoter Both in Plants and Bacteria. Biochemical and Biophysical Research Communications 204, 187-194.

Miyagawa A., Okami T., Kira N., Yamaguchi H., Ohnishi K. and Adachi M. (2009). Research note: High efficiency transformation of the diatom Phaeodactylum tricornutum with a promoter from the diatom Cylindrotheca fusiformis. Phycological Research 57, 142146.

Miyagawa-Yamaguchi A., Okami T., Kira N., Yamaguchi H., Ohnishi K. and Adachi M. (2011). Stable nuclear transformation of the diatom Chaetoceros sp. Phycological Research 59, 113-119.

Moellering E. R., Miller R. and Benning C. (2009). Molecular genetics of lipid metabolism in the model green alga Chlamydomonas reinhardtii. In"Advances in Photosynthesis and Respiration". Lipids in Photosynthesis: Essential and Regulatory Functions" (H. Wada and N. Murata, eds.), pp. 139-155. Springer.

Moellering E. R. and Benning C. (2010). RNA interference silencing of a major lipid droplet protein affects lipid droplet size in Chlamydomonas reinhardtii. Eukaryotic Cell 9, 97106.

Molina Grima E., Sanchez Perez J. A., Garcia Camacho F., Medina A. R., Gimenez A. G. and D. L. A. (1995). The production of polyunsaturated fatty acids by microalgae: from strain selection to product purification. Process Biochemistry 30, 711-719.

Morin P. J. (2008). Sex as an algal antiviral strategy. Proceedings of the National Academy of Sciences of the United States of America 105, 15639-15640.

Muhlhaus T., Weiss J., Hemme D., Sommer F. and Schroda M. (2011). Quantitative Shotgun Proteomics Using a Uniform 15N-Labeled Standard to Monitor Proteome Dynamics in Time Course Experiments Reveals New Insights into the Heat Stress Response of Chlamydomonas reinhardtii. Molecular \& Cellular Proteomics 10,(9) doi: 10.1074/mcp.M110.004739.

Nagasaki K. (2008). Dinoflagellates, diatoms, and their viruses. Journal of Microbiology 46, 235-243.

Nelson J. and Lefebvre P. (1995). Targeted disruption of the NIT8 gene in Chlamydomonas reinhardtii. Molecular and Cellular Biology 15, 5762-5769.

Neupert J., Karcher D. and Bock R. (2009). Generation of Chlamydomonas strains that efficiently express nuclear transgenes. Plant Journal 57, 1140-1150.

Nguyen P., Falcone D. L. and Graves M. V. (2009). The A312L 5 '-UTR of Chlorella virus PBCV-1 is a translational enhancer in Arabidopsis thaliana. Virus Research 140, 138146.

Nissimov J. I., Worthy C. A., Rooks P., Napier J. A., Kimmance S. A., Henn M. R., Ogata H. and Allen M. J. (2011). Draft Genome Sequence of the Coccolithovirus Emiliania huxleyi Virus 203. Journal of Virology 85, 13468-13469.

Niu Y. F., Zhang M. H., Xie W. H., Li J. N., Gao Y. F., Yang W. D., Liu J. S. and Li H. Y. (2011). A new inductible expression system in a transformed green alga, Clorella vulgaris. Genetic Molecular Research 10, (4) 3427-3434.

Norsker N. H., Barbosa M. J., Vermue M. H. and Wijffels R. H. (2011). Microalgal production: A close look at the economics. Biotechnology Advances 29, 24-27.

Norton T. A., Melkonian M. and Andersen R. A. (1996). Algal biodiversity. Phycologia 35, 308-326.

Ohnuma M., Yokoyama T., Inouye T., Sekine Y. and Tanaka K. (2008). Polyethylene glycol (PEG)-mediated transient gene expression in a red alga, Cyanidioschyzon merolae 10D. Plant and Cell Physiology 49, 117-120. 
Ohnuma M., Misumi O., Fujiwara T., Watanabe S., Tanaka K. and Kuroiwa T. (2009). Transient gene suppression in a red alga, Cyanidioschyzon merolae 10D. Protoplasma 236, 107-112.

Ohresser M., Matagne R. F. and Loppes R. (1997). Expression of the arylsulphatase reporter gene under the control of the nit1 promoter in Chlamydomonas reinhardtii. Current Genetics 31, 264-271.

Pan, K., Qin J. J., Li S., Dai W. K., Zhu B. H., Jin Y. C., Yu W. G., Yang G. P., and Li D. F. (2011). Nuclear Monoploidy and Asexual Propagation of Nannochloropsis Oceanica (Eustigmatophyceae) as Revealed by Its Genome Sequence. Journal of Phycology 47, 1425-1432.

Peled E., Leu S., Zarka A., Weiss M., Pick U., Khozin-Goldberg I. and Boussiba S. (2011). Isolation of a Novel Oil Globule Protein from the Green Alga Haematococcus pluvialis (Chlorophyceae). Lipids 46, 851-861.

Petruccelli S., Otegui M. S., Lareu F., Dinh O. T., Fitchette A. C., Circosta A., Rumbo M., Bardor M., Carcamo R., Gomord V. and Beachy R. N. (2006). A KDEL-tagged monoclonal antibody is efficiently retained in the endoplasmic reticulum in leaves, but is both partially secreted and sorted to protein storage vacuoles in seeds. Plant Biotechnology Journal 4, 511-527.

Potvin G. and Zhang Z. (2010). Strategies for high-level recombinant protein expression in transgenic microalgae: A review. Biotechnology Advances 28, 910-918.

Poulsen N. and Kroger N. (2005). A new molecular tool for transgenic diatoms: control of mRNA and protein biosynthesis by an inducible promoter-terminator cassette. FEBS Journal 272, 3413-3423.

Poulsen N., Chesley P. and Kroger N. (2006). Molecular genetic manipulation of the diatom Thalassiosira pseudonana (Bacillariophyceae). Journal of Phycology 42, 1059-1065.

Quinn J. M. and Merchant S. (1995). 2 Copper-Responsive Elements Associated with the Chlamydomonas Cyc6 Gene-Function as Targets for Transcriptional Activators. The Plant Cell 7, 623-638.

Radakovits R., Jinkerson R. E., Darzins A. and Posewitz M. C. (2010). Genetic Engineering of Algae for Enhanced Biofuel Production. Eukaryotic Cell 9, 486-501.

Ramazanov A. and Ramazanov Z. (2006). Isolation and characterization of a starchless mutant of Chlorella pyrenoidosa STL-PI with a high growth rate, and high protein and polyunsaturated fatty acid content. Phycological Research 54, 255-259.

Rasala B. A., Muto M., Lee P. A., Jager M., Cardoso R. M. F., Behnke C. A., Kirk P., Hokanson C. A., Crea R., Mendez M. and Mayfield S. P. (2010). Production of therapeutic proteins in algae, analysis of expression of seven human proteins in the chloroplast of Chlamydomonas reinhardtii. Plant Biotechnology Journal 8, 719-733.

Rasala B. A. and Mayfield S. (2011a). The microalgae Chlamydomonas reinhardtii as a platform for the production of human protein therapeutics. Bioengineered bugs 2, 5054.

Rasala B. A., Muto M., Sullivan J. and Mayfield S. P. (2011b). Improved heterologous protein expression in the chloroplast of Chlamydomonas reinhardtii through promoter and 5 ' untranslated region optimization. Plant Biotechnology Journal 9, 674-683.

Raven J. A. and Falkowski P. G. (1999). Oceanic sinks for atmospheric $\mathrm{CO}_{2}$. Plant, Cell and Environment 22, 741-755.

Rismani-Yazdi H., Haznedaroglu B. Z., Bibby K. and Peccia J. (2011). Transcriptome sequencing and annotation of the microalgae Dunaliella tertiolecta: Pathway description and gene discovery for production of next-generation biofuels. BMC Genomics 12, doi:10.1186/1471-2164-12-148.

Rolland N., Atteia A., Decottignies P., Garin J., Hippler M., Kreimer G., Lemaire S. p. D., Mittag M. and Wagner V. (2009). Chlamydomonas proteomics. Current Opinion in Microbiology 12, 285-291.

Rouxel C., Bougaran G., Doulin-Grouas S., Dubois N. and Cadoret J.-P. (2011). Novel isochrysis sp tahitian clone and uses therefore. EP 11006712.1., EU. 
Sakaue K., Harada H. and Matsuda Y. (2008). Development of gene expression system in a marine diatom using viral promoters of a wide variety of origin. Physiologia Plantarum 133, 59-67.

Sasso S., Pohnert G., Lohr M., Mittag M. and Hertweck C. (2011). Microalgae in the postgenomic era: a blooming reservoir for new natural products. FEMS Microbiology doi:10.1111/j.1574-6976.2011.00304.

Sastre R. R. and Posten C. (2010). The Variety of Microalgae Applications as a Renewable Resource. Chemie Ingenieur Technik 82, 1925-1939.

Schiedlmeier B., Schmitt R., Muller W., Kirk M. M., Gruber H., Mages W. and Kirk D. L. (1994). Nuclear Transformation of Volvox-Carteri. Proceedings of the National Academy of Sciences of the United States of America 91, 5080-5084.

Schmidt, F. R. (2004). Recombinant expression systems in the pharmaceutical industry. Microbiology and Biotechnology 65, 363-372.

Schroda M., Blocker D. and Beck C. F. (2000). The HSP70A promoter as a tool for the improved expression of transgenes in Chlamydomonas. Plant Journal 21, 121-131.

Schroeder D. C., Oke J., Malin G. and Wilson W. H. (2002). Coccolithovirus (Phycodnaviridae): Characterisation of a new large dsDNA algal virus that infects Emiliania huxleyi. Archives of Virology 147, 1685-1698.

Sekar S. and Chandramohan M. (2008). Phycobiliproteins as a commodity: trends in applied research, patents and commercialization. Journal of Applied Phycology 20, 113-136.

Shaish A., Ben-Amotz A. and Avron M. (1991). Production and selection of high betacarotene mutants of Dunaliella bardawil (Chlorophyta). Journal of Phycology 27, 652656.

Sheehan, J., Dunahay T., Benemann J., and Roessler P. (1998). A Look Back at the U.S. Department of Energy's Aquatic Species program: Biodiesel from Algae. In US Report NREL/TP-580-24190" (US Dpt of Energy), pp. 323. Golden. USA.

Siaut M., Heijde M., Mangogna M., Montsant A., Coesel S., Allen A., Manfredonia A., Falciatore A. and Bowler C. (2007). Molecular toolbox for studying diatom biology in Phaeodactylum tricornutum. Gene 406, 23-35.

Siaut M., Cuiné S., Cagnon C., Fessler B., Nguyen M., Carrier P., Beyly A., Beisson F., Triantaphylidès C., Li-Beisson Y. and Peltier G. (2011). Oil accumulation in the model green alga Chlamydomonas reinhardtii: characterization, variability between common laboratory strains and relationship with starch reserves. BMC Biotechnology 11, doi:10.1186/1472-6750-11-7.

Sizova I., Fuhrmann M. and Hegemann P. (2001). A Streptomyces rimosus aphVIII gene coding for a new type phosphotransferase provides stable antibiotic resistance to Chlamydomonas reinhardtii. Gene 277, 221-229.

Spetch E., Miyake-Stoner S. and Mayfield S. (2010). Micro-algae come of age as a platform for recombinant protein production. Biotechnology Letters 32, 1373-1383.

Spolaore P., Joannis-Cassan C., Duran E. and Isambert A. (2006). Commercial Applications of Microalgae. Journal of Bioscience and Bioengineering 101, 87-96.

Steinbrenner J. and Sandmann G. (2006). Transformation of the green alga Haematococcus pluvialis with a phytoene desaturase for accelerated astaxanthin biosynthesis. Applied and Environmental Microbiology 72, 7477-7484.

Stevens D. R., Rochaix J. D. and Purton S. (1996). The bacterial phleomycin resistance gene ble as a dominant selectable marker in Chlamydomonas. Molecular \& General Genetics 251, 23-30.

Sun M., Qian K. X., Su N., Chang H. Y., Liu J. X. and Chen G. F. (2003). Foot-and-mouth disease virus VP1 protein fused with cholera toxin B subunit expressed in Chlamydomonas reinhardtii chloroplast. Biotechnology Letters 25, 1087-1092.

Sun, Y., Yang Z. Y., Gao X. S., Li Q. Y., Zhang Q. Q., and Xu Z. K. (2005). Expression of foreign genes in Dunaliella by electroporation. Molecular Biotechnology 30, 185-192

Surzycki R., Greenham K., Kitayama K., Dibal F., Wagner R., Rochaix J.-D., Ajam T. and Surzycki S. (2009). Factors effecting expression of vaccines in microalgae. Biologicals 37, 133-138. 
Tan C., Qin S., Zhang Q., Jiang P. and Zhao F. (2005). Establishment of a micro-particle bombardment transformation system for Dunaliella salina. Journal of Microbiology 43, 361-365.

Tang D., Qiao S. and Wu M. (1995). Insertion mutagenesis of Chlamydomonas reinhardtii by electroporation and heterologous DNA. Biochemistry and Molecular Biology International 36, 1025-1035.

Ten Lohuis M. R. and Miller D. J. (1998). Genetic transformation of dinoflagellates (Amphidinium and Symbiodinium): expression of GUS in microalgae using heterologous promoter constructs. Plant Journal 13, 427-435.

Teng C., Qin S., Liu J., Yu D., Liang C. and Tseng C. (2002). Transient expression of lacZ in bombarded nicellular green alga Haematococcus pluvialis. Journal of Applied Phycology 14, 495-500.

Thomas R., Grimsley N., Escande M. L., Subirana L., Derelle E. and Moreau H. (2011). Acquisition and maintenance of resistance to viruses in eukaryotic phytoplankton populations. Environmental Microbiology 13, 1412-1420.

Tran, N., Park J., Hong S., and Lee C. (2009a). Proteomics of proteins associated with astaxanthin accumulation in the green algae Haematococcus lacustris under the influence of sodium orthovanadate. Biotechnology Letters 31, 1917-1922.

Tran, M., Zhou B., Pettersson P. L., Gonzalez M. J., and Mayfield S. P. (2009b). Synthesis and Assembly of a Full-Length Human Monoclonal Antibody in Algal Chloroplasts. Biotechnology and Bioengineering 104, 663-673.

Van Etten J. L. and Dunigan D. D. (2012). Chloroviruses: not your everyday plant virus. Trends in Plant Science 17, 1-8.

Villalobos A., Ness J. E., Gustafsson C., Minshull J. and Govindarajan S. (2006). Gene Designer: a synthetic biology tool for constructing artificial DNA segments. BMC Bioinformatics 7, doi:10.1186/1472-2105-7-285.

Von Dassow P., Ogata H., Probert I., Wincker P., Da Silva C., Audic S., Claverie J. and De Vargas C. (2009). Transcriptome analysis of functional differentiation between haploid and diploid cells of Emiliania huxleyi, a globally significant photosynthetic calcifying cell. Genome Biology, 10, doi:10.1186/gb-2009-10-10-r114.

Walker T. L., Collet C. and Purton S. (2005). Algal transgenics in the genomic ERA. Journal of Phycology 41, 1077-1093.

Wallis J. G. and Browse J. (2010). Lipid biochemists salute the genome. Plant Journal 61, $1092-1106$.

Wang C. H., Wang Y. Y., Su Q. and Gao X. R. (2007a). Transient expression of the GUS gene in a unicellular marine green alga, Chlorella sp MACC/C95, via electroporation. Biotechnology and Bioprocess Engineering 12, 180-183.

Wang, T. Y., Xue L. X., Hou W. H., Yang B. S., Chai Y. R., Ji X. A., and Wang Y. F. (2007b). Increased expression of transgene in stably transformed cells of Dunaliella salina by matrix attachment regions. Applied Microbiology and Biotechnology 76, 651-657.

Wang X. F., Brandsma M., Tremblay R., Maxwell D., Jevnikar A. M., Huner N. and Ma S. W. (2008). A novel expression platform for the production of diabetes-associated autoantigen human glutamic acid decarboxylase (hGAD65). BMC Biotechnology, 8, doi:10.1186/1472-6750-8-87.

Wang Z. T., Ullrich N., Joo S., Waffenschmidt S. and Goodenough U. (2009). Algal Lipid Bodies: Stress Induction, Purification, and Biochemical Characterization in Wild-type and Starch-less Chlamydomonas reinhardtii. Eukaryotic Cell 8, 12, 1856-1868.

Watanabe S., Ohnuma M., Sato J., Yoshikawa H. and Tanaka K. (2011). Utility of a GFP reporter system in the red alga Cyanidioschyzon merolae. Journal of General and Applied Microbiology 57, 69-72.

Weber A., Oesterhelt C., Gross W., Brautigam A., Imboden L., Krassovskaya I., Linka N., Truchina J., Schneidereit J., Voll H., Voll L., Zimmermann M., Jamai A., Riekhof W., Yu B., Garavito R. and Benning C. (2004). EST-analysis of the thermo-acidophilic red microalga Galdieria sulphuraria reveals potential for lipid A biosynthesis and unveils the pathway of carbon export from rhodoplasts. Plant Molecular Biology 55, 17-32. 
Wijffels, R. H., Barbosa M. J., and Eppink M. H. M. (2010). Microalgae for the production of bulk chemicals and biofuels. Biofuels, Bioproducts and Biorefining 4, 287-295.

Wilson, W. H., Van Etten J. L., and Allen M. J. (2009). The Phycodnaviridae: The Story of How Tiny Giants Rule the World. Current topics in microbiology and immunology, 328 $1-42$.

Winter J. M., Behnken S. and Hertweck C. (2011). Genomics-inspired discovery of natural products. Current Opinion in Chemical Biology 15, 22-31.

Yamano T. and Fukuzawa H. (2009). Carbon-concentrating mechanism in a green alga, Chlamydomonas reinhardtii, revealed by transcriptome analyses. Journal of Basic Microbiology 49, 42-51.

Yang Z. Q., Li Y. N., Chen F., Li D., Zhang Z. F., Liu Y. X., Zheng D. X., Wang Y. and Shen G. F. (2006). Expression of human soluble TRAIL in Chlamydomonas reinhardtii chloroplast. Chinese Science Bulletin 51, 1703-1709.

Yu S., Liu S., Li C. and Zhou Z. (2011). Submesoscale characteristics and transcription of a fatty acid elongase gene from a freshwater green microalgae, Myrmecia incisa Reisigl. Chinese Journal of Oceanology and Limnology 29, 87-95.

Zaslavskaia L. and Lippmeier J. C. (2000). Transformation of the diatom Phaeodactylum tricornutum (Bacillariophyceae) with a variety of selectable marker and reporter genes. Journal of Phycology 36, 379-386.

Zhang Y. K., Shen G. F. and Ru B. G. (2006). Survival of human metallothionein-2 transplastomic Chlamydomonas reinhardtii to ultraviolet B exposure. Acta Biochimica Et Biophysica Sinica 38, 187-193.

Zhao R., Cao Y., Xu H., Lv L., Qiao D. and Cao Y. (2011). Analysis of Expressed Sequence Tags From The Green Alga Dunaliella Salina (Chlorophyta). Journal of Phycology 47, 1454-1460. 
Tables

Tables 1 : Ongoing microalgae transcriptomic projects

\begin{tabular}{|c|c|c|c|}
\hline Phylum & Species & Strain & Status \\
\hline Bacillariophyta & Asterionellopsis glacialis & 1712 & Assembly \& Annotation \\
\hline Bacillariophyta & Chaetoceros sp. & & Assembly \& Annotation \\
\hline Bacillariophyta & Corethron hystrix & 308 & Assembly \& Annotation \\
\hline Bacillariophyta & Cylindrotheca closterium & & Assembly \& Annotation \\
\hline Bacillariophyta & Grammatophora oceanica & 410 & Assembly \& Annotation \\
\hline Bacillariophyta & Melosira sp. & CCMP 2643 & Sequencing \\
\hline Bacillariophyta & Navicula transitans & 80 & Assembly \& Annotation \\
\hline Bacillariophyta & Odontella sp. & & Assembly \& Annotation \\
\hline Bacillariophyta & Odontella sinensis & Grunow 1884 & Sequencing \\
\hline Bacillariophyta & Skeletonema costatum & 1716 & Sequencing \\
\hline Bacillariophyta & Stephanopyxis turris & CCMP 815 & Sequencing \\
\hline Chlorarachniophyta & Lotharella oceanica & CCMP622 & Assembly \& Annotation \\
\hline Chlorarachniophyta & Lotharella globosa & LEX01 & Assembly \& Annotation \\
\hline Chlorarachniophyta & Lotharella amoebiformis & CCMP2058 & Assembly \& Annotation \\
\hline Chlorarachniophyta & Bigelowiella natans & CCMP 2755 & Assembly \& Annotation \\
\hline Chlorophyta & Crustomastix stigmata & CCMP3273 & Sequencing \\
\hline Chlorophyta & Dolichomastix tenuilepis & СCMP3274 & Sequencing \\
\hline Chlorophyta & Micromonas sp. & CCMP2099 & Assembly \& Annotation \\
\hline Chlorophyta & Nephroselmis pyriformis & CCMP717 & Assembly \& Annotation \\
\hline Chlorophyta & Pyramimonas parkeae & CCMP725 & Assembly \& Annotation \\
\hline Chlorophyta & Tetraselmis sp. & GSL018 & Sequencing \\
\hline Cryptophyta & Chroomonas mesostigmatica & CCMP1168 & Assembly \& Annotation \\
\hline Cryptophyta & Cryptomonas paramecium & CCAP977/2a & Assembly \& Annotation \\
\hline Cryptophyta & Goniomonas pacifica & CCMP1869 & Sequencing \\
\hline Cryptophyta & Guillardia theta & CCMP2712 & Assembly \& Annotation \\
\hline Cryptophyta & Hemiselmis andersenii & CCMP644 & Sequencing \\
\hline Dinophyta & Alexandrium minutum & CCMP113 & Sequencing \\
\hline Dinophyta & Crypthecodinium cohnii & Seligo & Sequencing \\
\hline Dinophyta & Karenia brevis & SP3 & Sequencing \\
\hline Dinophyta & Oxyrrhis marina & CCMP788 & Assembly \& Annotation \\
\hline Dinophyta & Oxyrrhis marina & CCMP1795 & Sequencing \\
\hline Dinophyta & Symbiodinium kawagutii & CCMP2468 & Sequencing \\
\hline Euglenophyta & Eutreptiella gymnastica & NIES-381 & Assembly \& Annotation \\
\hline Haptophyta & Hyalolithus neolepis & TMR5 & Sequencing \\
\hline Ochrophyta & Dinobryon sp. & UTEXLB2267 & Assembly \& Annotation \\
\hline Ochrophyta & Ochromonas sp. & CCMP 1393 & Assembly \& Annotation \\
\hline Rhodophyta & Rhodosorus marinus & 769 & Assembly \& Annotation \\
\hline
\end{tabular}

Source : from http://marinemicroeukaryotes.org/project_organisms 


\begin{tabular}{|c|c|c|c|c|c|}
\hline $\begin{array}{l}\text { Gene } \\
\text { expressed }\end{array}$ & Function & $\begin{array}{l}\text { Host species and cell } \\
\text { localization }\end{array}$ & $\begin{array}{l}\text { Expression level } \\
\text { achieved }\end{array}$ & Application & Source \\
\hline HSV8-lsc & Mammalian antibody & $\begin{array}{l}\text { Chlamydomonas } \\
\text { reinhardtii, Chloroplast }\end{array}$ & Detectable & Pharmaceutical & (Mayfield et al. 2003) \\
\hline CTB-VP1 & $\begin{array}{l}\text { Cholera toxin B subunit } \\
\text { fused to foot and mouth } \\
\text { disease VP1 }\end{array}$ & $\begin{array}{l}\text { Chlamydomonas } \\
\text { reinhardtii, Chloroplast }\end{array}$ & $3 \%$ TSP & Vaccine & (Sun et al. 2003) \\
\hline HSV8-scFv & $\begin{array}{l}\text { Classic single-chain } \\
\text { antibody }\end{array}$ & $\begin{array}{l}\text { Chlamydomonas } \\
\text { reinhardtii, Chloroplast }\end{array}$ & $0.5 \% \mathrm{TSP}$ & Pharmaceutical & (Mayfield et al. 2005) \\
\hline hMT-2 & $\begin{array}{l}\text { Human } \\
\text { metallothionine-2 }\end{array}$ & $\begin{array}{l}\text { Chlamydomonas } \\
\text { reinhardtii, Chloroplast }\end{array}$ & Detectable & $\begin{array}{l}\text { Pharmaceutical, } \\
\text { UV-protection }\end{array}$ & (Zhang et al. 2006) \\
\hline hTRAIL & $\begin{array}{l}\text { Human tumor necrosis } \\
\text { factor-related } \\
\text { apoptosis-inducing } \\
\text { ligand (TRAIL) }\end{array}$ & $\begin{array}{l}\text { Chlamydomonas } \\
\text { reinhardtii, Chloroplast }\end{array}$ & $\sim 0.67 \%$ TSP & Pharmaceutical & (Yang et al. 2006) \\
\hline M-SAA & $\begin{array}{l}\text { Bovine mammary- } \\
\text { associated serum } \\
\text { amyloid }\end{array}$ & $\begin{array}{l}\text { Chlamydomonas } \\
\text { reinhardtii, Chloroplast }\end{array}$ & $\sim 5 \%$ TSP & $\begin{array}{l}\text { Therapeutics, } \\
\text { oral delivery }\end{array}$ & (Manuell et al. 2007) \\
\hline CSFV-E2 & $\begin{array}{l}\text { Swine fever virus E2 } \\
\text { viral protein }\end{array}$ & $\begin{array}{l}\text { Chlamydomonas } \\
\text { reinhardtii, Chloroplast }\end{array}$ & $\sim 2 \%$ TSP & Vaccine & (He et al. 2007) \\
\hline hGAD65 & $\begin{array}{l}\text { Diabetes-associated } \\
\text { anutoantigen human } \\
\text { glutamic acid } \\
\text { decarboxylase } 65\end{array}$ & $\begin{array}{l}\text { Chlamydomonas } \\
\text { reinhardtii, Chloroplast }\end{array}$ & $\sim 0.3 \% \mathrm{TSP}$ & $\begin{array}{l}\text { Diagnostics and } \\
\text { therapeutics }\end{array}$ & (Wang et al. 2008) \\
\hline $83 \mathrm{~K} 7 \mathrm{C}$ & $\begin{array}{l}\text { Full-length IgG1 human } \\
\text { monoclonal antibody } \\
\text { against anthrax } \\
\text { protective antigen } 83\end{array}$ & $\begin{array}{l}\text { Chlamydomonas } \\
\text { reinhardtii, Chloroplast }\end{array}$ & $\begin{array}{l}0.01 \% \text { dry algal } \\
\text { biomass }\end{array}$ & Therapeutics & (Tran et al. 2009b) \\
\hline IgG1 & $\begin{array}{l}\text { Murine and human } \\
\text { antibodies (LC and } \mathrm{HC} \text { ) }\end{array}$ & $\begin{array}{l}\text { Chlamydomonas } \\
\text { reinhardtii, Chloroplast }\end{array}$ & Detectable & Therapeutics & (Tran et al. 2009b) \\
\hline VP28 & $\begin{array}{l}\text { White spot syndrome } \\
\text { virus protein } 28\end{array}$ & $\begin{array}{l}\text { Chlamydomonas } \\
\text { reinhardtii, Chloroplast }\end{array}$ & $\sim 10.5 \%$ TSP & Vaccine & (Surzycki et al. 2009) \\
\hline CTB-D2 & $\begin{array}{l}\text { D2 fibronectin-binding } \\
\text { domain of } \\
\text { Staphylococcus aureus } \\
\text { fused with the cholera } \\
\text { toxin B subunit }\end{array}$ & $\begin{array}{l}\text { Chlamydomonas } \\
\text { reinhardtii, Chloroplast }\end{array}$ & $0.7 \% \mathrm{TSP}$ & Oral vaccine & (Dreesen et al. 2010) \\
\hline $\begin{array}{l}\text { 10NF3, } \\
14 \mathrm{FN} 3\end{array}$ & $\begin{array}{l}\text { Domains } 10 \text { and } 14 \text { of } \\
\text { human fibronectin }\end{array}$ & $\begin{array}{l}\text { Chlamydomonas } \\
\text { reinhardtii, Chloroplast }\end{array}$ & $\begin{array}{l}\text { 14FN3: 3\% TSP } \\
\text { 10FN3: detectable }\end{array}$ & Therapeutics & (Rasala et al. 2010) \\
\hline $\begin{array}{l}\text { M-SAA- } \\
\text { Interferon } \\
\beta 1\end{array}$ & $\begin{array}{l}\text { Multiple sclerosis } \\
\text { treatment fused to M- } \\
\text { SAA }\end{array}$ & $\begin{array}{l}\text { Chlamydomonas } \\
\text { reinhardtii, Chloroplast }\end{array}$ & Detectable & Therapeutics & (Rasala et al. 2010) \\
\hline Proinsulin & $\begin{array}{l}\text { Blood sugar level- } \\
\text { regulating hormone, } \\
\text { type I diabetes } \\
\text { treatment }\end{array}$ & $\begin{array}{l}\text { Chlamydomonas } \\
\text { reinhardtii, Chloroplast }\end{array}$ & Detectable & Therapeutics & (Rasala et al. 2010) \\
\hline VEGF & $\begin{array}{l}\text { Human vascular } \\
\text { endothelial growth } \\
\text { factor isoform } 121\end{array}$ & $\begin{array}{l}\text { Chlamydomonas } \\
\text { reinhardtii, Chloroplast }\end{array}$ & $2 \% \mathrm{TSP}$ & Therapeutics & (Rasala et al. 2010) \\
\hline HMGB1 & $\begin{array}{l}\text { High mobility group } \\
\text { protein B1 }\end{array}$ & $\begin{array}{l}\text { Chlamydomonas } \\
\text { reinhardtii, Chloroplast }\end{array}$ & $2.5 \% \mathrm{TSP}$ & Therapeutics & (Rasala et al. 2010) \\
\hline NP-1 & $\begin{array}{l}\text { Rabbit neutrophil } \\
\text { peptide-1 }\end{array}$ & $\begin{array}{l}\text { Chlorella ellipsoidea, } \\
\text { nuclear }\end{array}$ & Detectable & Antimicrobial & (Chen et al. 2001) \\
\hline $\begin{array}{l}\text { ARS2- } \\
\text { crEpo-his6 }\end{array}$ & $\begin{array}{l}\text { Human erythropoietin } \\
\text { fused to ARS2 export } \\
\text { sequence w/6xhis tag }\end{array}$ & $\begin{array}{l}\text { Chlamydomonas } \\
\text { reinhardtii, Nuclear }\end{array}$ & $100 \mu \mathrm{g} / \mathrm{L}$ culture & $\begin{array}{l}\text { Pharmaceutical, } \\
\text { protein export }\end{array}$ & $\begin{array}{l}\text { (Eichler-Stahlberg et } \\
\text { al. 2009) }\end{array}$ \\
\hline $\begin{array}{l}\text { CL4mAb } \\
\text { and HBsAg }\end{array}$ & $\begin{array}{l}\text { Human antibody } \\
\text { CL4mAB and the } \\
\text { Hepatitis B surface } \\
\text { antigen (HBsAg) }\end{array}$ & $\begin{array}{l}\text { Phaeodactylun } \\
\text { tricornutum, Nuclear }\end{array}$ & $\begin{array}{l}\text { CL4mAb: } 8.7 \% \text { TSP } \\
\text { HBsAg: } 0.7 \% \text { TSP }\end{array}$ & Vaccine & (Hempel et al. 2011b) \\
\hline mEPO & Murine Erythropoietin & $\begin{array}{l}\text { Phaeodactylun } \\
\text { tricornutum, Nuclear }\end{array}$ & $300 \mu \mathrm{g} / \mathrm{L}$ culture & Therapeutics & $\begin{array}{l}\text { (Carlier A, } \\
\text { unpublished work) }\end{array}$ \\
\hline
\end{tabular}

Source: modified from Spetch et al. (2011). Recent successes in therapeutic protein production in algae. 
Table 3: Promoter Used For Microalgae Genetic Transformation

\begin{tabular}{|c|c|c|c|c|}
\hline Host species of Microalgae & Promoter of gene and its product & $\begin{array}{l}\text { Cell } \\
\text { expression } \\
\text { localization }\end{array}$ & Source of promoter & Source \\
\hline \multirow{17}{*}{$\begin{array}{l}\text { Chlamydomonas } \\
\text { reinhardtii }\end{array}$} & $\arg 7$, arginosuccinate lyase & Nuclear & Chlamydomonas reinhardtii & (Debuchy, 1989) \\
\hline & $35 \mathrm{~S}$, cauliflower mosaic virus $35 \mathrm{~S}$ & Nuclear & Cauliflower mosaic virus & $\begin{array}{l}\{\text { Brown, 1991) } \\
\text { (Tang et al., 1995) } \\
\text { (Kumar et al., 2004) }\end{array}$ \\
\hline & $R b c S 2$, rubisco small subunit 2 & Nuclear & Chlamydomonas reinhardtii & $\begin{array}{l}\text { (Auchincloss et al., 1999) } \\
\text { (Fuhrmann et al., 1999) } \\
\text { (Sizova et al., 2001) } \\
\text { (Stevens et al., 1996) } \\
\text { (Nelson and Lefebvre, } \\
\text { 1995) } \\
\text { (Kovar et al., 2002) } \\
\text { (Cerutti et al., 1997) } \\
\text { (Cordero, 2011) }\end{array}$ \\
\hline & $\begin{array}{l}H S P 70 \text {, heat shock protein } 70 \text { (fused } \\
\text { to other promoter) }\end{array}$ & Nuclear & Chlamydomonas reinhardtii & $\begin{array}{l}\text { (Schroda et al., 2000) } \\
\text { (Eichler-Stahlberg et al., } \\
\text { 2009) }\end{array}$ \\
\hline & Nos, nopaline synthase & Nuclear & Agrobacterium tumefaciens & (Hall et al., 1993) \\
\hline & Nit1, nitrate assimilation 1 & Nuclear & Chlamydomonas reinhardtii & $\begin{array}{l}\text { (Ohresser et al., 1997) } \\
\text { (Llamas et al., 2002) }\end{array}$ \\
\hline & Cop, chlamyopsin & Nuclear & Chlamydomonas reinhardtii & (Fuhrmann et al., 1999) \\
\hline & TubA1, alpha-tubulin & Nuclear & Chlamydomonas reinhardtii & (Kozminski et al., 1993) \\
\hline & $\beta 2$-tubulin & Nuclear & Chlamydomonas reinhardtii & $\begin{array}{l}\text { (Blankenship and Kindle, } \\
\text { 1992) } \\
\text { (Berthold et al., 2002) }\end{array}$ \\
\hline & CabII-1, chlorophyl-ab binding & Nuclear & Chlamydomonas reinhardtii & $\begin{array}{l}\text { (Blankenship and Kindle, } \\
\text { 1992) }\end{array}$ \\
\hline & pcyl, plastocyanin & Nuclear & Chlamydomonas reinhardtii & $\begin{array}{l}\text { (Quinn and Merchant, } \\
\text { 1995) }\end{array}$ \\
\hline & $\begin{array}{l}\text { atp } C \text {, gamma-subunit of chloroplast } \\
\text { ATPase }\end{array}$ & Nuclear & Chlamydomonas reinhardtii & $\begin{array}{l}\text { (Quinn and Merchant, } \\
\text { 1995) }\end{array}$ \\
\hline & $\begin{array}{l}\text { psaD, photosystem I complex } \\
\text { protein }\end{array}$ & Nuclear & Chlamydomonas reinhardtii & $\begin{array}{l}\text { (Fischer and Rochaix, } \\
\text { 2001) }\end{array}$ \\
\hline & $\begin{array}{l}\text { atp } A \text {, alpha subunit of adenosine } \\
\text { triphosphate }\end{array}$ & Chloroplast & Chlamydomonas reinhardtii & (Sun et al., 2003) \\
\hline & psbD, photosystem II D1 & Chloroplast & Chlamydomonas reinhardtii & (Manuell et al., 2007) \\
\hline & $\begin{array}{l}R b c L, \text { ribulose bisphosphate } \\
\text { carboxylase large subunit }\end{array}$ & Chloroplast & Chlamydomonas reinhardtii & (Dreesen et al., 2010) \\
\hline & psbA, photosystem II psbA & Chloroplast & Chlamydomonas reinhardtii & (Rasala et al., 2011b) \\
\hline \multirow[t]{4}{*}{ Dunaliella salina } & Ubil- $\Omega$, ubiquitin- $\Omega$ & Nuclear & Zea mais & (Geng et al., 2003) \\
\hline & $35 \mathrm{~S}$, cauliflower mosaic virus $35 \mathrm{~S}$ & Nuclear & Cauliflower mosaic virus & $\begin{array}{l}\text { (Tan et al., 2005) } \\
\text { (Sun et al., 2005) } \\
\text { (Feng et al., 2009) } \\
\text { (Wang et al., 2007b) }\end{array}$ \\
\hline & $N R$, Nitrate reductase & Nuclear & Dunaliella salina & $\begin{array}{l}\text { (Li et al., 2007) } \\
\text { (Li et al., 2008a) }\end{array}$ \\
\hline & $R b c S 2$, rubisco small subunit & Nuclear & Dunaliella salina & (Sun et al., 2005) \\
\hline Dunaliella bardawil & $35 S$, cauliflower mosaic virus $35 \mathrm{~S}$ & Nuclear & Cauliflower mosaic virus & (Anila et al., 2011) \\
\hline \multirow[t]{3}{*}{ Chlorella ellipsoida } & $35 S$, cauliflower mosaic virus $35 \mathrm{~S}$ & Nuclear & Cauliflower mosaic virus & (Jarvis and Brown, 1991) \\
\hline & Ubil- $\Omega$, ubiquitin- $\Omega$ & Nuclear & Zea mais & (Chen et al., 2001) \\
\hline & $R b c S 2$, rubisco small subunit 2 & Nuclear & Chlamydomonas reinhardtii & (Kim et al., 2002) \\
\hline Chlorella sorokiniana & $N R$, nitrate reductase & Nuclear & Chlorella sp. & (Dawson, 1997) \\
\hline \multirow[t]{2}{*}{ Chlorella vulgaris } & $35 \mathrm{~S}$, cauliflower mosaic virus $35 \mathrm{~S}$ & Nuclear & Cauliflower mosaic virus & $\begin{array}{l}\text { (Cha et al., 2011b) } \\
\text { (Chow and Tung, 1997) } \\
\text { (Chow and Tung, 1999) } \\
\text { (Wang et al., 2007a) }\end{array}$ \\
\hline & $N R$, nitrate reductase & Nuclear & Phaeodactylum tricornutum & (Niu et al., 2011) \\
\hline Platymonas subcodiformis & $C M V$, cytomegalovirus & Nuclear & Cytomegalovirus & (Cui et al., 2010) \\
\hline
\end{tabular}




\begin{tabular}{|c|c|c|c|c|}
\hline \multirow[t]{3}{*}{ Nannochloropsis sp } & $\begin{array}{l}H S P 70 \text {, heat shock protein } 70 / \\
R b c S 2 \text {, rubisco small subunit } 2\end{array}$ & Nuclear & Chlamydomonas reinhardtii & $\begin{array}{l}\text { (Chen et al., 2008) } \\
\text { (Li and Tsai, 2008b) }\end{array}$ \\
\hline & $35 \mathrm{~S}$, cauliflower mosaic virus $35 \mathrm{~S}$ & Nuclear & Cauliflower mosaic virus & (Cha et al., 2011a) \\
\hline & $\begin{array}{l}V C P \text {, violaxanthin/chlorophyl } \\
\text { binding protein }\end{array}$ & Nuclear & Nannochloropsis sp & (Kilian et al., 2011) \\
\hline \multirow[t]{3}{*}{ Haematococcus pluvialis } & $S V 40$, simian virus & Nuclear & simian virus & (Teng et al., 2002) \\
\hline & $p d s$, phytoene desaturase & & Haematococcus pluvialis & $\begin{array}{l}\text { (Steinbrenner and } \\
\text { Sandmann, 2006) }\end{array}$ \\
\hline & $35 \mathrm{~S}$, cauliflower mosaic virus $35 \mathrm{~S}$ & Nuclear & Cauliflower mosaic virus & (Kathiresan et al., 2009) \\
\hline Volvox carteri & $N R$, nitrate reductase & Nuclear & Volvox carteri & (Schiedlmeier et al., 1994) \\
\hline Gonium pectorale & $\begin{array}{l}\text { psD, photosystem I complex protein } \\
\text { / HSP } 70, \text { heat shock protein } 70\end{array}$ & & Chlamydomonas reinhardtii & $\begin{array}{l}\text { (Lerche and hallmann, } \\
\text { 2009) }\end{array}$ \\
\hline $\begin{array}{l}\text { Closterium peracerosum- } \\
\text { strigosum litorrale }\end{array}$ & $\begin{array}{l}H S P 70 \text { heat shock protein } 70 / C a b, \\
\text { chlorophyl-ab binding } \mathrm{Ch} \text { a/b- } \\
\text { binding protein }\end{array}$ & & $\begin{array}{l}\text { Closterium peracerosum- } \\
\text { strigosum litorrale }\end{array}$ & $\begin{array}{l}\text { (Abe et al., 2008) } \\
\text { (Abe et al., 2011) }\end{array}$ \\
\hline Lotharella amoebiformis & $R b c S 2$, rubisco small subunit 2 & Nuclear & Lotharella amoebiformis & (Hirakawa et al., 2008) \\
\hline Cyclotella criptyca & $A c c 1$, acetylCoA carboxylase & Nuclear & Cyclotella criptyca & (Dunahay et al., 1995) \\
\hline Navicula saprophila & $A c c 1$, acetylCoA carboxylase & Nuclear & Cyclotella criptyca & (Dunahay et al., 1995) \\
\hline \multirow{7}{*}{$\begin{array}{l}\text { Phaeodactylum } \\
\text { tricornutum }\end{array}$} & $f c p A / B / C / E$, fucoxanthin chlorophyll & Nuclear & Phaeodactylum tricornutum & (Apt et al., 1996) \\
\hline & $f_{c p} F$, fucoxanthin chlorophyll & Nuclear & Phaeodactylum tricornutum & (Falciatore et al., 1999) \\
\hline & $f_{c p} A$, fucoxanthin chlorophyll & Nuclear & Phaeodactylum tricornutum & (Zaslavskaia et al., 2000) \\
\hline & $c a h$, carbonic anyhdrase & Nuclear & Phaeodactylum tricornutum & $\begin{array}{l}\text { (Harada and Matsuda, } \\
\text { 2005) }\end{array}$ \\
\hline & $\begin{array}{l}C M V \text {, cytomegalovirus; } P R S V-L T R, \\
\text { rous sarcoma virus; } 35 S \text {, cauliflower } \\
\text { mosaic virus } 35 \mathrm{~S}\end{array}$ & Nuclear & $\begin{array}{l}\text { Cytomegalovirus; Rous } \\
\text { sarcoma virus; Cauliflower } \\
\text { mosaic virus }\end{array}$ & (Sakaue et al., 2008) \\
\hline & $f_{c p} A$, fucoxanthin chlorophyll & Nuclear & Phaeodactylum tricornutum & (Coesel et al., 2009) \\
\hline & $\begin{array}{l}f_{c p} \text {, fucoxanthin chlorophyll and } N R \text {, } \\
\text { nitrate reductase }\end{array}$ & Nuclear & Cylindrotheca fusiformis & (Miyagawa et al., 2009) \\
\hline \multirow[t]{2}{*}{ Cylindrotheca fusiformis } & $\mathrm{P} \delta$, frustulin $\alpha 3$ & Nuclear & Cylindrotheca fusiformis & (Fischer et al., 1999) \\
\hline & $N R$, nitrate reductase & Nuclear & Cylindrotheca fusiformis & (Poulsen and Kroger, 2005) \\
\hline Thalassiosira pseudonana & $f_{c p}$, fucoxanthin chlorophyll & Nuclear & Thalassiosira pseudonana & (Poulsen et al., 2006) \\
\hline Thalassiosira weissflogii & $f_{c p} B$, fucoxanthin chlorophyll & Nuclear & Thalassiosira pseudonana & (Falciatore et al., 1999) \\
\hline Chaetoceros sp. & $\begin{array}{l}p T p N R \text { (nitrate reductase de } \\
\text { Thallassiosira psudomana) }\end{array}$ & Nuclear & Thalassiosira pseudonana & $\begin{array}{l}\text { (Miyagawa-Yamaguchi et } \\
\text { al., 2011) }\end{array}$ \\
\hline $\begin{array}{l}\text { Amphidinium spp. } \\
\text { Symbiodinium } \\
\text { microadriaticum }\end{array}$ & $35 \mathrm{~S}$, cauliflower mosaic virus $35 \mathrm{~S}$ & Nuclear & Cauliflower mosaic virus & $\begin{array}{l}\text { (ten Lohuis and Miller, } \\
\text { 1998) }\end{array}$ \\
\hline \multirow[t]{4}{*}{ Cyanidioschyzon merolae } & UMP synthase & Nuclear & Cyanidioschyzon merolae & (Minoda et al., 2004) \\
\hline & $\beta$-tubulin & Nuclear & Cyanidioschyzon merolae & (Ohnuma et al., 2008) \\
\hline & cat, catalase & Nuclear & Cyanidioschyzon merolae & (Ohnuma et al., 2009) \\
\hline & $\begin{array}{l}\text { apc } C \text {, phycocyanin-associated } \\
\text { protein }\end{array}$ & Nuclear & Cyanidioschyzon merolae & (Watanabe et al., 2011) \\
\hline Porphyidium sp. & $A H A S$, acetohydroxyacid synthase & Nuclear & Porphyidium sp. & (Lapidot et al., 2002) \\
\hline Euglena gracilis & $\begin{array}{l}\text { psbA, photosystem II complex } \\
\text { protein }\end{array}$ & Chloroplast & Euglena gracilis & (Doetsch et al., 2001) \\
\hline
\end{tabular}

